\title{
Bioinspired recognition elements for mycotoxin sensors
}

\author{
Riikka Peltomaa $^{1} \cdot$ Elena Benito-Peña $^{1} \cdot$ María C. Moreno-Bondi $^{1}$
}

Received: 27 July 2017 / Revised: 5 October 2017 / Accepted: 10 October 2017 /Published online: 10 November 2017

(C) Springer-Verlag GmbH Germany 2017

\begin{abstract}
Mycotoxins are low molecular weight molecules produced as secondary metabolites by filamentous fungi that can be found as natural contaminants in many foods and feeds. These toxins have been shown to have adverse effects on both human and animal health, and are the cause of significant economic losses worldwide. Sensors for mycotoxin analysis have traditionally applied elements of biological origin for the selective recognition purposes. However, since the 1970 s there has been an exponential growth in the use of genetically engineered or synthetic biomimetic recognition elements that allow some of the limitations associated with the use of natural receptors for the analyses of these toxins to be circumvented. This review provides an overview of recent advances in the application of bioinspired recognition elements, including recombinant antibodies, peptides, aptamers, and molecularly imprinted polymers, to the development of sensors for mycotoxins based on different transduction elements.
\end{abstract}

Keywords Mycotoxin $\cdot$ Recognition element $\cdot$ Recombinant antibody $\cdot$ Peptide $\cdot$ Aptamer $\cdot$ Molecularly imprinted polymer

Published in the topical collection celebrating ABCs 16th Anniversary.

María C. Moreno-Bondi

mcmbondi@ucm.es

1 Department of Analytical Chemistry, Faculty of Chemistry, Universidad Complutense de Madrid, Av. Complutense s/n, 28040 Madrid, Spain

\section{Introduction}

Mycotoxins are low molecular weight (approximately 700) natural products produced as secondary metabolites by filamentous fungi mainly, although not exclusively, when they reach maturity [1]. Unlike primary metabolites, these compounds are believed to have no function in the life cycle of the producer cell [2]. They can be found as natural contaminants in many vegetal foods or feeds, including nuts (almonds and walnuts), cereals (rice, wheat, and maize), oilseeds (soybean, peanuts), fruits, dried fruits, spices, beans, forage, wines, and grape juices, or in foods of animal origin, such as milk, eggs, and meat [1,2]. Alternatively, exposure to these toxins can be by inhalation of dust containing mycotoxigenic fungal spores [1]. Regardless of the way they come in contact with humans or domestic animals, including birds, they may cause lowered performance, sickness, or even death even at very low concentrations $[3,4]$. Their range of actions includes cytotoxic, nephrotoxic, hepatotoxic, teratogenic, mutagenic, carcinogenic, immunosuppressive, and estrogenic effects [1,2]. In any case, their effect on health depends on factors such as the concentration in the contaminated food and the exposure time, the synergistic effect of other mycotoxins, and environmental factors associated especially with the storage conditions of the foodstuff [1].

The word "mycotoxin," a combination of the Greek word for "fungus" mykes and the Latin word toxicum, meaning "poison" [5], was established in 1962 after the "turkey X disease" responsible for the death of approximately 100,000 turkey poults near London, due to the intake of feed infested with secondary metabolites from Aspergillus flavus (aflatoxins) [6]. Nowadays, approximately 400 compounds are recognized as mycotoxins, although only about 30 
molecules are considered as a threat to human and animal health [3]. Mycotoxins may contaminate crops before or after harvest. As an example, deoxynivalenol (DON) and T-2 toxin, two toxins produced by Fusarium species, appear before harvest, ochratoxins (from Aspergillus and Penicillium) occur after harvest, and aflatoxins (from Aspergillus) can be produced at any stage of the production chain, from before harvest to storage [7]. The mycotoxins that show the highest occurrence rate and the severest effects on human and animal health include aflatoxins, fumonisins, ochratoxins, 3nitropropionic acid, trichothecenes, ergot alkaloids, citrinin (CIT), and zearalenone (ZEN) (Table 1) [9]. Additionally, the presence of toxin precursors, metabolites, degradation products, or the so-called masked mycotoxins is also a potential threat to consumer safety. The presence of these compounds may increase the toxicity of food commodities with an apparently low concentration of the parental toxin. Moreover, their detection is in many cases still in its infancy. Such metabolites and masked mycotoxins have been reported at least for trichothecenes, fumonisins, ochratoxin A (OTA), and ZEN [10].

Mycotoxin-producing molds are extremely common, and they grow under a wide range of conditions, which often makes mycotoxin contamination inevitable [3]. As the presence of these toxins in food and animal feeds can have severe health effects as well as important economic consequences, several national and international authorities, including the European Commission, have set maximum residue limits for the most common and most toxic mycotoxins (Table 2) [11-15]. The limits differ depending on the toxin and the foodstuff in question; the strictest regulations have been set for aflatoxins and the processed food products for infants. In addition to the toxin regulations for foodstuff, European Commission regulations include also the presence of mycotoxins in animal feed [16, 17].

To meet the regulations and to ensure food safety, novel analytical methods are needed to detect and quantify these toxic molecules at trace concentrations. Conventionally, mycotoxins are detected by chromatography, immunoassays, or sensors. While chromatographic methods, mostly high-performance liquid chromatography coupled with diode array, fluorescence, or mass spectrometry detection, offer high sensitivity and accuracy, they have some limitations related to their high cost and long analysis time and the requirement of highly skilled personnel and tedious sample cleanup [18-21]. In this sense, immunoassays can be considered as an alternative for the rapid determination of these natural toxins, with the advantage that they are usually low cost while maintaining the required sensitivity and specificity. Moreover, sensors for mycotoxin detection can offer real-time readout and perform the entire process automatically $[22,23]$.

Table 1 Most abundant and toxic mycotoxins, their most important producers, and their most important effects $[2,3,8]$

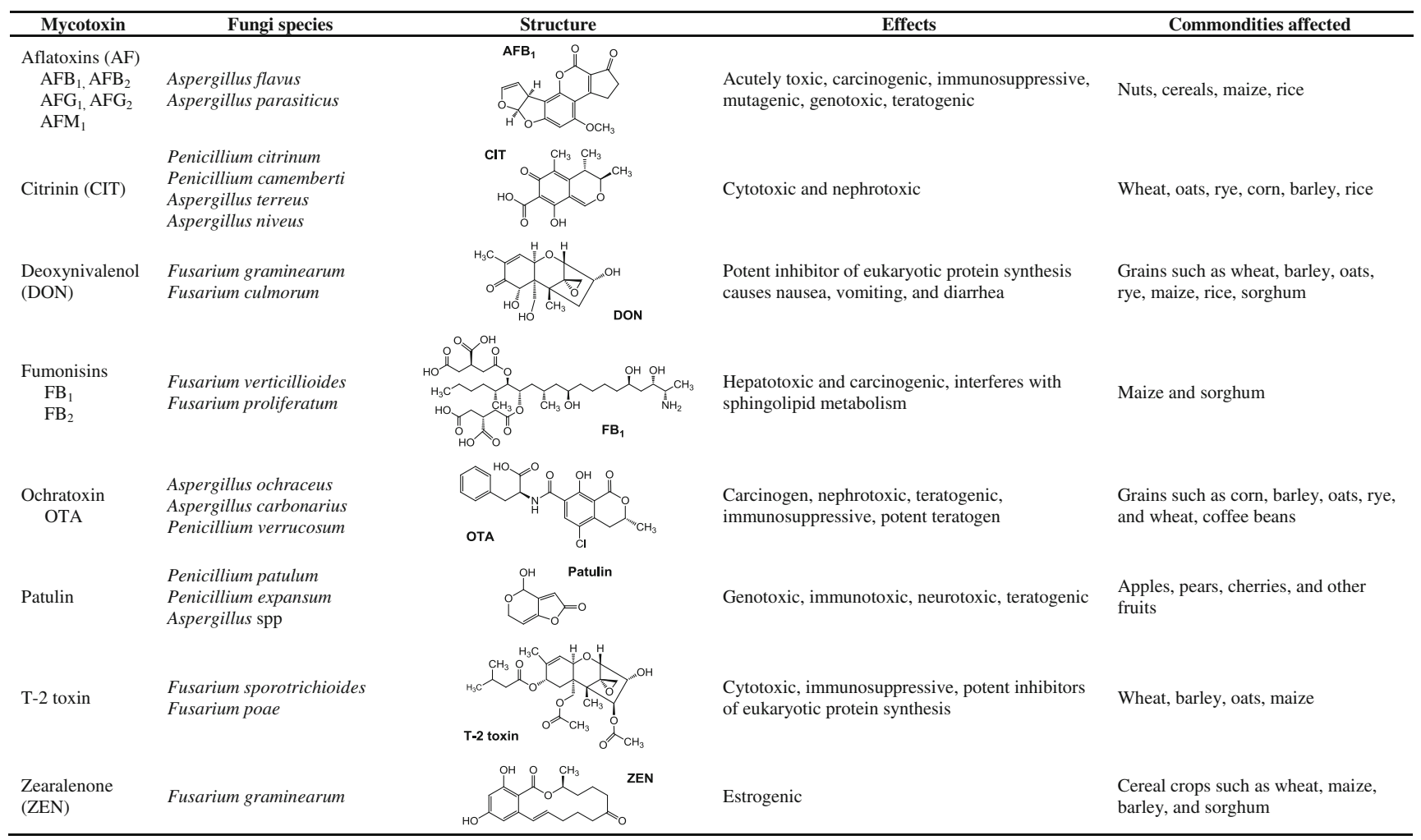


Table 2 Regulations and recommendations for mycotoxins by the European Commission [11-15]

\begin{tabular}{|c|c|c|c|}
\hline Mycotoxin & $\begin{array}{l}\text { Maximum limit } \\
(\mu \mathrm{g} / \mathrm{kg})\end{array}$ & Foodstuffs & Regulation \\
\hline \multicolumn{4}{|l|}{ Alfatoxins } \\
\hline Aflatoxin $\mathrm{B}_{1}$ & $0.10-12.0$ & Nuts, dried fruit, cereals and cereal products, maize, spices & EC No. $1881 / 2006$ \\
\hline Sum of aflatoxins $B_{1}, B_{2}, G_{1}$ and $G_{2}$ & $4.0-15.0$ & Milk & EC No. $165 / 2010$ \\
\hline Aflatoxin $\mathrm{M}_{1}$ & $0.025-0.050$ & & \\
\hline Deoxynivalenol & $200-1750$ & Unprocessed cereals and maize, pasta, bread, cereal-based infant food & $\begin{array}{l}\text { EC No. } 1881 / 2006 \\
\text { EC No. } 1126 / 2007\end{array}$ \\
\hline Fumonisins & $200-4000$ & Unprocessed maize and maize-based foods & EC No. $1881 / 2006$ \\
\hline Sum of Fumonisins $B_{1}$ and $B_{2}$ & & & EC No. $1126 / 2007$ \\
\hline Ochratoxin A & $0.50-10.0$ & $\begin{array}{l}\text { Cereals and cereal products, dried vine fruit, coffee, spices, wine } \\
\text { and grape juice }\end{array}$ & $\begin{array}{l}\text { EC No. } 1881 / 2006 \\
\text { EC No. } 105 / 2010\end{array}$ \\
\hline Patulin & $10.0-50$ & Fruit juices, apple products, cereal-based infant food & EC No. $1881 / 2006$ \\
\hline T-2 and HT-2 toxins & $15-1000$ & Unprocessed cereals and cereal products & EC No. $165 / 2013$ \\
\hline \multicolumn{4}{|l|}{ Sum of T-2 and HT- 2 toxins } \\
\hline Zearalenone & $20-350$ & Cereals, maize, cereal- and maize-based product, bread & $\begin{array}{l}\text { EC No. } 1881 / 2006 \\
\text { EC No. } 1126 / 2007\end{array}$ \\
\hline
\end{tabular}

The most crucial element of all immunoassays and sensors is the recognition element, which makes possible the specific detection of the target analyte, and the quality of the recognition element often defines the specificity and sensitivity of the analysis [24, 25]. Especially in the case of competitive assays, which is usually the format selected to detect low molecular weight targets, such as mycotoxins, the importance of the recognition element is eminent as the sensitivity of competitive assays is highly dependent on the affinity of the recognition element [26]. To develop a sensitive and specific method, the recognition element must be able to detect the analyte even at low concentrations and to distinguish the target from other similar molecules, such as other toxins that can be present in the same sample [27]. Other factors affecting the selection of the recognition element include cost, availability, and compatibility, as well as stability and shelf life.

Antibodies are the gold standard recognition elements in biosensors and assays, and they have proven their superiority over the years in terms of specificity and sensitivity. For the detection of mycotoxins, the first polyclonal antibodies were described more than 40 years ago [28] and they were soon complemented by monoclonal antibodies [29, 30]. During the last few decades, numerous applications besides the traditional ELISA have been described, and excellent sensitivities have been reported recently, for example, with magnetic beads for improved separation [31-33], or novel detection schemes, including new label-based approaches [34-36] and label-free approaches [37-40]. Many polyclonal and monoclonal antibodies as well as ELISA-based test kits are commercially available, and antibodies indisputably continue their reign as the recognition element of choice [41, 42]. Nevertheless, despite their wide use, antibodies have some limitations mostly related to high cost and low stability, for example, to high temperatures or stringent conditions. Owing to their large and complex structure, antibodies are able to specifically bind their target antigen but, at the same time, the complex structure is susceptible to denaturation, degradation, or aggregation. Moreover, production of monoclonal antibodies by hybridoma technology is usually time-consuming and inherently dependent on animal immunization [26, 41]. Small analytes, such as mycotoxins, are often difficult targets for antibody development as they are too small to be recognized by the immune system, and thus require conjugation to a carrier molecule [26]. In addition, some commercial antibodies have been demonstrated to have high cross-reactivity, which limits their application to real samples, where several toxins can be present simultaneously [43-45].

Novel recognition elements have the potential to overcome the limitations related to monoclonal and polyclonal antibodies. Not only can the sensitivity and specificity be increased, but, perhaps even more importantly, the robustness, simplicity, and price of the method can be affected, making it possible to develop methods suitable for high-throughput screening or low-resource settings. In this review, we introduce some recent advances in the development of novel bioinspired recognition elements, including recombinant antibodies, peptides, aptamers, and molecularly imprinted polymers (MIPs), for the detection of mycotoxins.

\section{Recombinant antibodies}

Antibodies are widely used for biosensing because of their unique properties and immense variety of possible specificities. Naturally, antibodies are produced by the immune system in B-cell lymphocytes to function as antigen receptors for the cell. The vast recognition variety relies on the variations introduced during the transcription process of the $\mathrm{B}$ cells by combinatorial assembly of the gene fragments, and further, by additional mutations after the primary recognition [46]. For 
decades, polyclonal and monoclonal antibodies have been the cornerstone of most mycotoxin detection methods, but gradually they have been complemented by other antibody formats. The conventional IgG antibody (approximately 150 $\mathrm{kDa})$ consists of two identical heavy polypeptide chains (50 $\mathrm{kDa})$ and two identical light polypeptide chains $(25 \mathrm{kDa})$ that are linked to each other by disulfide bonds (Fig. 1a). The light and the heavy chains both have one variable domain $\left(\mathrm{V}_{\mathrm{L}}\right.$ and $\mathrm{V}_{\mathrm{H}}$, respectively), and additionally the light chain has a single constant domain, whereas the heavy chain contains three or four constant domains. The two antigen-binding fragments (Fabs) are responsible for binding to the target, whereas the highly conserved $\mathrm{Fc}$ region (fragment crystallizable) interacts with effector molecules and cells $[46,48]$. The most relevant region, from the analytical point of view, is the antigenbinding site, or paratope, which is rather small compared with size of the total antibody. The concept of reducing the size of the antibody while conserving the antigen-binding properties has long been known, and enzymatic digestion has traditionally been used to generate antibody fragments $[25,46]$.

More recently, advancements in recombinant DNA technology and protein engineering have made it possible to modify the antibody structure and develop recombinant antibodies that possess several advantageous characteristics, such as smaller size and easy production, while preserving the target specificity of the intact antibody [49]. The best known antibody fragments are the Fab fragment $(55 \mathrm{kDa}$ ) and the even smaller scFv (single chain fragment variable; $25 \mathrm{kDa}$ ), which consists only of the $\mathrm{V}_{\mathrm{H}}$ and $\mathrm{V}_{\mathrm{L}}$ domains, which are joined by a synthetic polypeptide linker (Fig. 1a) [49]. The small size of recombinant antibody fragments has several advantages, including the decrease of nonspecific binding often caused by the Fc region of the intact IgG, and the possibility to immobilize the antibodies at higher density. Furthermore, novel recombinant antibodies can theoretically be selected within a couple of weeks, which can be considered a major advantage compared with the development of polyclonal and monoclonal antibodies, where immunizations inevitably take several months $[26,27]$. Antibody fragments, unlike full-length antibodies, can be propagated in bacteria, such as Escherichia coli, which significantly lowers the cost of production as no specialized cell culture facilities for hybridoma cell lines are needed [50]. The technology has the potential to bypass the immune system and produce antibodies without the need to immunize animals. Generation of antibodies by in vitro display technologies has several advantages over the naturally derived antibodies, such as the control over the selection conditions and the great high-throughput potential, including parallelization, automation, and miniaturization [43]. Moreover, antibody engineering using different in vitro strategies, including chain shuffling and site-directed mutagenesis, permits further manipulation or modification of various antibody properties to achieve greater affinity or stability, eliminate unwanted cross-reactivities, or add tags for purification or immobilization [26, 48].

Recombinant antibodies can be derived from monoclonal antibodies by direct cloning of the gene fragments from the hybridoma cell lines and their expression in E. coli. For example, recombinant Fab fragment against DON [51] and scFvs against aflatoxin $\mathrm{B}_{1}\left(\mathrm{AFB}_{1}\right)$ [52], DON [53], and fumonisin $\mathrm{B}_{1}\left(\mathrm{FB}_{1}\right)$ [54] were derived directly from monoclonal antibodies. However, isolation of functional recombinant antibodies directly from hybridoma cell lines can be difficult, and the fragments often have lower affinity than the parental monoclonal antibody $[55,56]$. For example, the anti-FB ${ }_{1} \mathrm{scFv}$ produced by Min et al. [54], although specific toward $\mathrm{FB}_{1}$, had about 12 times lower affinity than the monoclonal antibody.

Alternatively, recombinant antibodies can be selected from recombinant antibody libraries, in essence mimicking the natural in vivo process of antibody production. The process
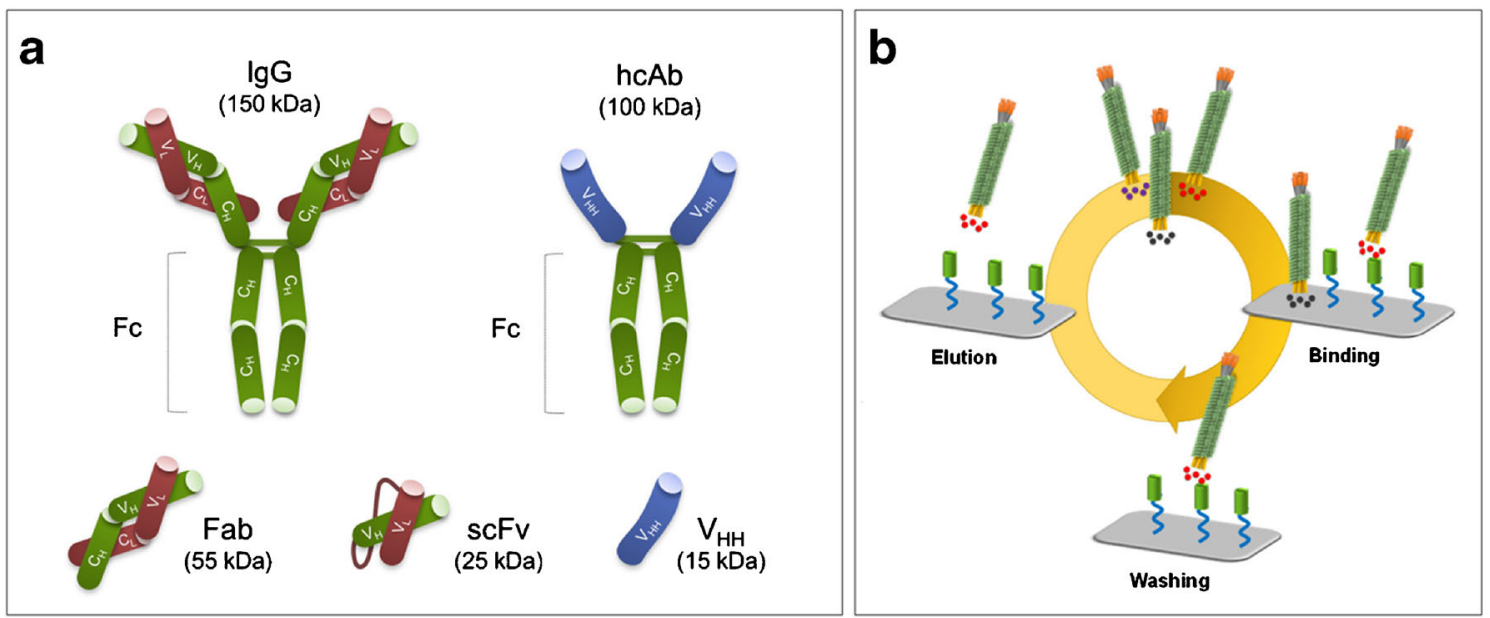

Fig. 1 a The conventional antibody ( $\operatorname{IgG}$ ), the heavy chain antibody (hcAb), and the most common recombinant antibody fragments (scFv, $\left.\mathrm{Fab}, \mathrm{V}_{\mathrm{HH}}\right)$. b General scheme of the phage display biopanning procedure.
$\mathrm{C}_{\mathrm{H}}$ constant heavy domain, $\mathrm{C}_{\mathrm{L}}$ constant light domain, $\mathrm{V}_{\mathrm{H}}$ variable heavy domain, $\mathrm{V}_{\mathrm{L}}$ variable light domain. (Adapted from [47]) 
includes (1) the generation of genotypic diversity, usually by construction of antibody libraries that consist of millions or billions of different antibody variants, (2) the display method, which creates a physical link between the expressed protein variant and the gene coding for it, (3) the application of selective pressure to screen the antibody libraries for target-specific binders, and (4) amplification of the selected variants [57]. By far the most used and most widespread technique for screening antibody libraries is phage display [58], which is based on bacterial viruses, bacteriophages, which can infect bacteria and use the bacterial cell for their own replication. Phages can be easily genetically engineered to display foreign peptides or proteins outside the virion as a fusion protein with one of the coat proteins. Peptides and small antibody fragments have been displayed on phages to create phage libraries consisting of millions of different phage clones that display the peptide or antibody fragment outside the virion while retaining the genetic material inside the capsule. This physical linkage allows easy selection of the target-specific binders in an in vitro screening process called "biopanning" (Fig. 1b). In the iterative panning procedure, a phage-displayed library is introduced to a target coated surface, and, after the unbound phages have bene washed away, the target-binding phages are eluted and amplified in E. coli to subject them to subsequent rounds of selection. Usually after three or four rounds of selection, individual target-specific clones can be selected and characterized [59]. Alternatively, the screening of the antibody repertoire can be based on yeast display [60], or cell-free systems, such as ribosome display [61]. Although not as popular as the phage display technology, these methods offer some advantages, such as the capability of yeast cells to express complex proteins that require posttranslational modifications, or the possibility to create larger libraries with use of cell-free methods that are not restricted by the bacterial transformation efficiency [62].

Recombinant antibody libraries can be constructed from natural sources by isolation of the B cells of animals, most often mice, immunized with the target antigen, and use of the corresponding genes to construct the antibody library [63]. Such immunized libraries are already biased toward the target, and they often, although not necessarily, result in high-affinity binders. However, the process is long and inherently dependent on animal immunization individually for each target. Phage-displayed $\mathrm{scFv}$ libraries have been constructed from immunized mice against $\mathrm{FB}_{1}$ [64], OTA [65], and ZEN [66]. Surface plasmon resonance (SPR) analysis revealed excellent affinities in the nanomolar range for the anti-OTA and antiZEN antibody fragments, demonstrating the advantage of using immunized libraries. In a different approach, so-called positive phage-displayed libraries have been constructed by random recombination of the $\mathrm{V}_{\mathrm{H}}$ and $\mathrm{V}_{\mathrm{L}}$ gene fragments from hybridoma cell lines that secrete a specific monoclonal antibody (Fig. 2a). Such libraries have been reported at least against $\mathrm{AFB}_{1}$ [56] and $\mathrm{FB}_{1}$ [55], both of which resulted in an $\mathrm{scFv}$ with increased affinity compared with the parental monoclonal antibody.

Alternatively, the library construction can be done completely in vitro, resulting in nonimmunized (naïve) [68], synthetic [69], or semisynthetic antibody libraries that contain higher sequential diversity and can be designed for screening of antibodies against a wide range of targets, or designed taking into account specific prerequisites so as to find antibodies, for example, against haptens [70]. The use of synthetic libraries has several advantages, such as the possibility to select antibodies against small or difficult targets that can be nonimmunogenic or highly toxic, but the library diversity has to be high enough to find binders with high affinity. Construction of such libraries is technically difficult and limited by the efficiency of the bacterial transformation [59]. For mycotoxins only a few examples of recombinant antibodies originating from naïve or synthetic libraries have been reported. Anti- $\mathrm{FB}_{1} \mathrm{scFv}$ selected from a naïve library showed affinity of only $K_{\mathrm{D}}=4.08 \times 10^{-7} \mathrm{M}$ [71], whereas anti-AFB ${ }_{1}$ screened from a synthetic human scFv library (Tomlinson J) showed excellent $K_{\mathrm{D}}$ of $1.2 \times 10^{-}$ ${ }^{12} \mathrm{M}$ [72]. Some examples of immunoassays based on recombinant antibodies are presented in Table 3.

Heavy chain antibodies, naturally produced by camelids and sharks, are an interesting subclass of antibodies that are completely devoid of the light chains (Fig. 1a) [76]. Thus, because of the lack of the $\mathrm{V}_{\mathrm{L}}$ domains, the antigen is recognized by a single domain and the paratope is composed of three hypervariable loops (instead of six in $\mathrm{IgG}$ ) [48]. The use of the single variable domain of heavy chain $\left(\mathrm{V}_{\mathrm{HH}}\right)$ antibodies has gained a lot of interest thanks to their specific characteristic and the extraordinary structure that makes them more suitable for some applications. The $\mathrm{V}_{\mathrm{HH}}$ antibody fragments, also known as "nanobodies" or "single domain antibodies," are the smallest available antigen-binding fragments, with a size of only $15 \mathrm{kDa}$, and they are robust and very stable in a variety of conditions, including high temperatures and denaturing conditions thanks to the hydrophilic residue substitutions in a specific region [48, 77]. Heavy chain antibodies are used in clinical and therapeutic applications but are also an interesting option for in vitro diagnostics.

Heavy chain antibodies $\left(\mathrm{V}_{\mathrm{HH}}\right)$, or nanobodies, are usually selected by construction of a phage-displayed library after immunization of an alpaca with the hapten conjugate. Although nanobodies have many ideal characteristics for biosensor applications, such as high stability and easy production, only a few examples of successful application for mycotoxins have been reported (Table 3). The most widely used nanobody was developed by Liu et al. [67] for the detection of OTA using an alpaca-derived $\mathrm{V}_{\mathrm{HH}}$ library. The nanobody $\mathrm{Nb} 28$ showed excellent performance in phage displaymediated immuno-polymerase chain reaction, with a detection limit of $3.7 \mathrm{pg} / \mathrm{L}$ (Fig. 2b), which is the lowest detection limit reported for OTA detection, although the high sensitivity is 

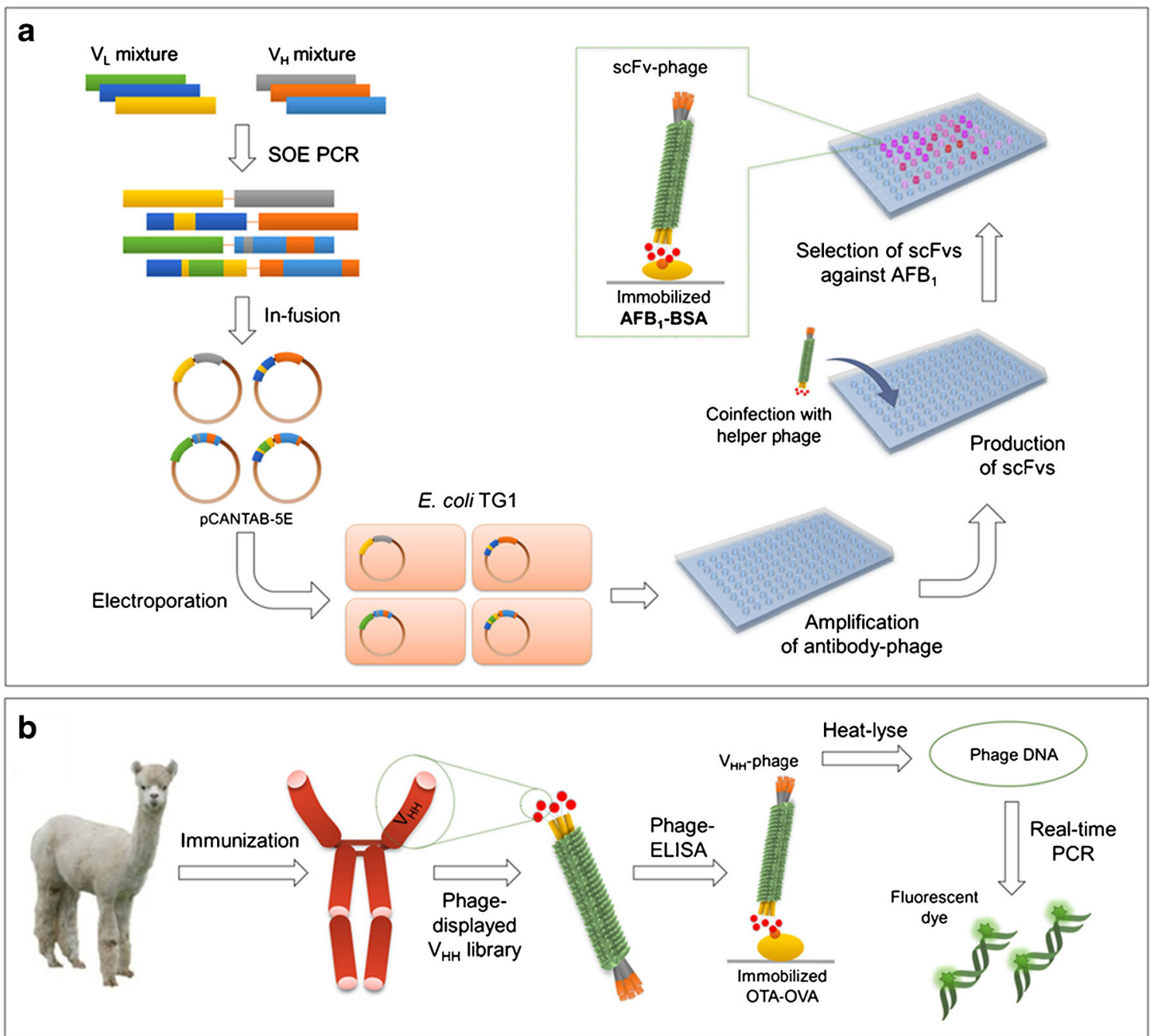

Fig. 2 a Construction of a positive phage-displayed library for the selection of high-affinity $\mathrm{scFv}$ antibodies for aflatoxin $\mathrm{B}_{1}\left(\mathrm{AFB}_{1}\right)$ detection. $\mathbf{b}$ Selection of ochratoxin A (OTA)-binding $V_{\mathrm{HH}}$ from an immunized library and the use of phage-displayed $\mathrm{V}_{\mathrm{HH}}$ in phage ELISA with

probably mostly attributed to the polymerase chain reaction based detection rather than the recognition element per se. An excellent example of the possibilities offered by protein engineering was described later when the same nanobody was expressed as a fusion with alkaline phosphatase and used in direct competitive fluorescence enzyme immunoassay with a detection limit of $0.04 \mathrm{ng} / \mathrm{mL}$ [75], and in nanobody-based ELISA with a detection limit of $0.16 \mathrm{ng} / \mathrm{mL}$ [78]. The nanobody-based ELISA had a slightly higher detection limit but the soluble nanobody had greater stability and it could retain the antigen-binding activity even after exposure to temperatures as high as $95^{\circ} \mathrm{C}$. Similar results regarding nanobody stability and tolerance to high temperatures and organic solvents were reported for an $\mathrm{AFB}_{1}$-specific nanobody selected also from an alpaca-derived $\mathrm{V}_{\mathrm{HH}}$ library. This competitive nanobody-based ELISA exhibited a half-maximal inhibitory concentration $\left(\mathrm{IC}_{50}\right)$ of $0.754 \mathrm{ng} / \mathrm{mL}$, and because of the high phage display-mediated immuno-polymerase chain reaction (PCR)-based detection. BSA bovine serum albumin, OVA ovalbumin. (a Adapted from [56]; $\mathbf{b}$ adapted from [67])

tolerance to methanol, sample extracts could be directly analyzed without dilution [74]. Recently, the OTA-specific nanobody $\mathrm{Nb} 28$ was used for the development of a membrane-based dot ELISA that allowed noninstrumental visual screening of OTA at $5 \mu \mathrm{g} / \mathrm{kg}$, and results could be obtained within $20 \mathrm{~min}$ [79].

Although nanobodies are widely praised and the few examples described here enlighten the many advantages of nanobodies, the discovery of hapten-binding nanobodies is difficult [80]. It has also been pointed out that nanobodies are not ideal binders for small molecules because they possess a limited number of conformational structures suitable for hapten recognition [81]. More nanobodies for mycotoxin detection have been reported to be used as epitope mimics (discussed in "Epitope mimics") rather than as primary antibodies, which might be a more appropriate application for this special class of antibodies because of the structure of their 


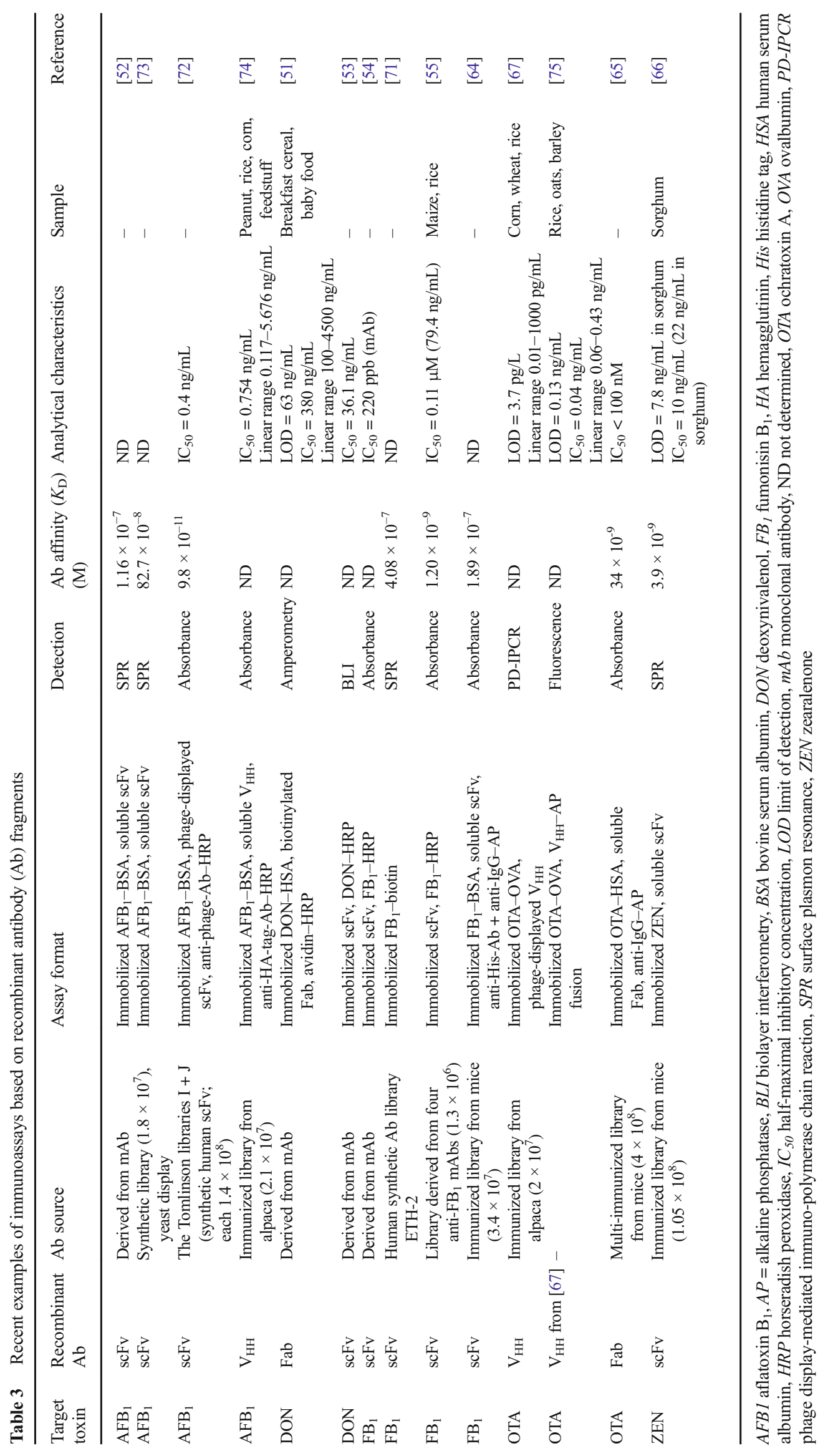


paratope, which is known to have better access cleft-like epitopes than conventional antibodies [49].

Low molecular weight molecules such as mycotoxins are usually detected in a competitive assay format that requires conjugation of the toxin to a label or a carrier molecule. Despite their wide use, such assays have many fundamental problems in respect to the specificity and sensitivity. As the sensitivity of competitive assays is mainly governed by the equilibrium constant of the antibody, these assays cannot fully exploit different alternatives in the assay design that can significantly increase the sensitivity in noncompetitive immunoassays [82]. In some cases, conjugation of the antigen can be difficult or result in randomly cross-linked or unstable molecules, which can reduce the antibody binding. Consequently, the noncompetitive or sandwich-type immunoassays are usually considered superior to the competitive assays and hold great potential for increased sensitivity and wider dynamic range. Conventionally, such a noncompetitive two-site assay format requires that the antigen has two separate epitopes where two antibodies can bind simultaneously, forming the "sandwich" complex [26]. Mycotoxins are small molecules, or haptens, which possess only one epitope and cannot bind more than one antibody simultaneously. That said, recombinant antibody technology has made it possible to develop nonconventional antibodies that can be used to detect also haptens in noncompetitive assays.

Open sandwich immunoassay (OS-IA), originally described by Ueda et al. [83] for the detection of lysozyme, is based on association of separated $\mathrm{V}_{\mathrm{H}}$ and $\mathrm{V}_{\mathrm{L}}$ chains in the presence of the antigen. OS-IA is an excellent example of a way to detect small molecules in a noncompetitive assay, and has been reported to outperform competitive assay in terms of sensitivity, working range, and assay time [84]. However, in any case the detection sensitivity depends strongly on the affinity of the antibody used and the differential interactions between separated $V_{H}$ and $V_{L}$ chains in the presence or absence of the target. Moreover, as only one antibody is involved, OS-IA can suffer from cross-reactivity [84, 85]. Suzuki et al. [86] developed an OS-IA for the detection of ZEN by using the split Fvs ( $\mathrm{V}_{\mathrm{H}}$ and $\mathrm{V}_{\mathrm{L}}$ chains) of a monoclonal anti-ZEN in phage display or fusion protein formats. Both noncompetitive assays showed superior performance compared with the competitive assay. However, despite the attractive scheme, unfortunately development of OS-IAs is difficult and time-consuming, and, to the best of our knowledge, this is the only reported OS-IA for the detection of mycotoxins. This hints, and as has been stated elsewhere [84], that it is often challenging to find antibodies that possess the required characteristics with differential interactions between separated $V_{H}$ and $V_{L}$ chains in the presence or absence of the antigen, which is the essence of the method.

Another alternative for small molecule noncompetitive immunoassay is to use anti-immune complex antibodies, also known as "anti-metatype antibodies," which bind to the primary antibody only when it is in complex with the antigen. Originally, anti-immune complex antibodies were monoclonal antibodies developed by immunization [87], but later phagedisplayed libraries with antibodies [88] or peptides [89, 90] were used as well. Noncompetitive immunoassays based on anti-immune complex antibodies have the added advantage of increased specificity owing to the use of two antibodies instead of one as in the competitive assay, as was seen in the work of Arola et al. [91, 92]. The group identified first HT-2specific binders from an immunized phage library and, subsequently, anti-immune complex antibodies from a naïve scFv library. Although the primary antibody showed crossreactivity between the highly similar toxins T-2 and HT-2, the use of anti-immune complex antibody made the assay specific for HT-2 toxin only. The antibodies developed were used in a homogeneous time-resolved fluorescence resonance energy transfer assay (Fig. 3a) [91] and later in heterogeneous ELISA with scFv-alkaline phosphatase fusion [92] for the detection of HT-2 with detection limits of 0.38 and $0.3 \mathrm{ng} /$ $\mathrm{mL}$, respectively. Compared with the competitive ELISA, the novel anti-immune complex assay was approximately ten times more sensitive in both cases, underlining the possibility for improved detection by the noncompetitive assay format.

\section{Epitope mimics}

As stated already, one major limitation of the competitive assay format is the requirement to conjugate the target toxin to a carrier molecule, usually a protein or a label, to allow immobilization or detection of this competitor. Synthesis of the toxin conjugates can be difficult and time-consuming, or can result in randomly cross-linked or unstable molecules, which can reduce the immunoassay sensitivity. Lot-to-lot variations of the conjugates, or even false positives caused by the release of the analyte moiety from the conjugate, are known to affect the assay reproducibility and accuracy [94, 95]. On the other hand, labeling the target toxin may alter the epitope and thus reduce or even abolish antibody recognition $[26,96]$. To overcome these drawbacks, a possible alternative is to develop protein or peptide substitutes that mimic the target mycotoxin and serve as the competitor in the competitive immunoassay. Such epitope mimics bind to the same antibody paratope as the target toxin and elicit an antibody response similar to that of the analyte. As epitope mimics can substitute for the toxins and the toxin conjugates used in the immunoassay, such applications can be considered more friendly for the user and the environment as the assay components are not toxic themselves [94]. Table 4 summarizes some recent examples of the use of epitope mimics in immunoassays for the detection of mycotoxins. These and several other reports have shown that epitope mimics can reduce the detection limits compared with 


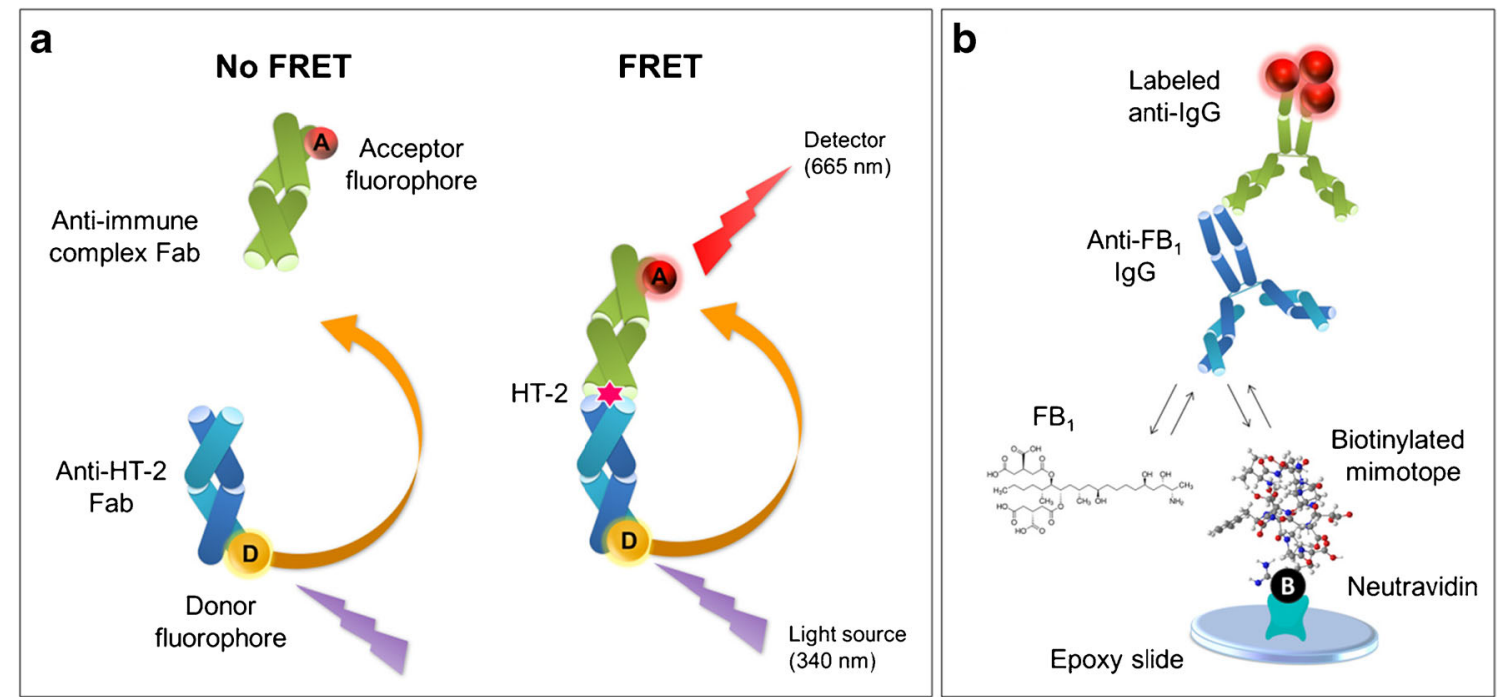

Fig. 3 a Homogeneous noncompetitive immunoassay for the detection of HT-2 toxin based on the anti-immune complex Fab, which binds to the primary antibody with HT-2 toxin. Fluorescence resonance energy transfer (FRET) occurs because of the short distance between the two fluorophores. b Microarray-based immunoassay for the detection of fumonisin $\mathrm{B}_{1}\left(\mathrm{FB}_{1}\right)$ using biotinylated mimotopes. (a Adapted from [91]; b adapted from [93])

variable. This structure is known to create rather large convex paratopes and allow better binding to clefts and cavities, which has been suggested to be more suitable for molecular mimicry of haptens [26, 100, 115]. For example, Wang et al. [97] selected an anti-idiotypic $\mathrm{V}_{\mathrm{HH}}$ from an immunized library for the detection of $\mathrm{AFB}_{1}$. The nanobody-based ELISA showed an $\mathrm{IC}_{50}$ of $13.8 \mu \mathrm{g} / \mathrm{kg}$ for $\mathrm{AFB}_{1}$ in spiked samples, which was further reduced fourfold with use of phage display-mediated immuno-polymerase chain reaction for the detection with the same nanobody [98].

Although nanobodies isolated from naïve phage-displayed libraries occasionally do not have enough affinity to be used as the primary antibody, they can be suitable as anti-idiotypic antibodies in competitive immunoassay. In this case, a slightly lower affinity of the epitope mimic can be advantageous as weaker affinity indicates less amount of the analyte needed to participate in the competition, which leads to higher sensitivities [100, 104]. In fact, the naïve alpaca nanobody phage-displayed library, originally constructed by $\mathrm{Tu}$ et al. [99] for screening of DONspecific nanobodies, $\mathrm{w}$ widely used thereafter for screening of anti-idiotypic nanobodies for the detection of several mycotoxins, including CIT [116, 117], DON [95], $\mathrm{FB}_{1}$ [100, 101], and OTA [104]. In all cases, the use of the anti-idiotypic nanobody increased the sensitivity of the ELISA, at best 20fold compared with the assays with the toxin conjugates.

Perhaps a simpler alternative to anti-idiotypic antibodies is the use of small peptides as epitope mimics. Such peptides, also known as "mimotopes," have been developed for the most common mycotoxins, including DON [112], $\mathrm{FB}_{1}$ [93, 102, 103], OTA [105, 106, 118-120], and ZEN [121]. Reported mimotopes differ in length and structure; use of linear 7-mer [106, 118] and 12-mer [93] peptides as well as cyclic complementarity-determining regions is unusually long and 


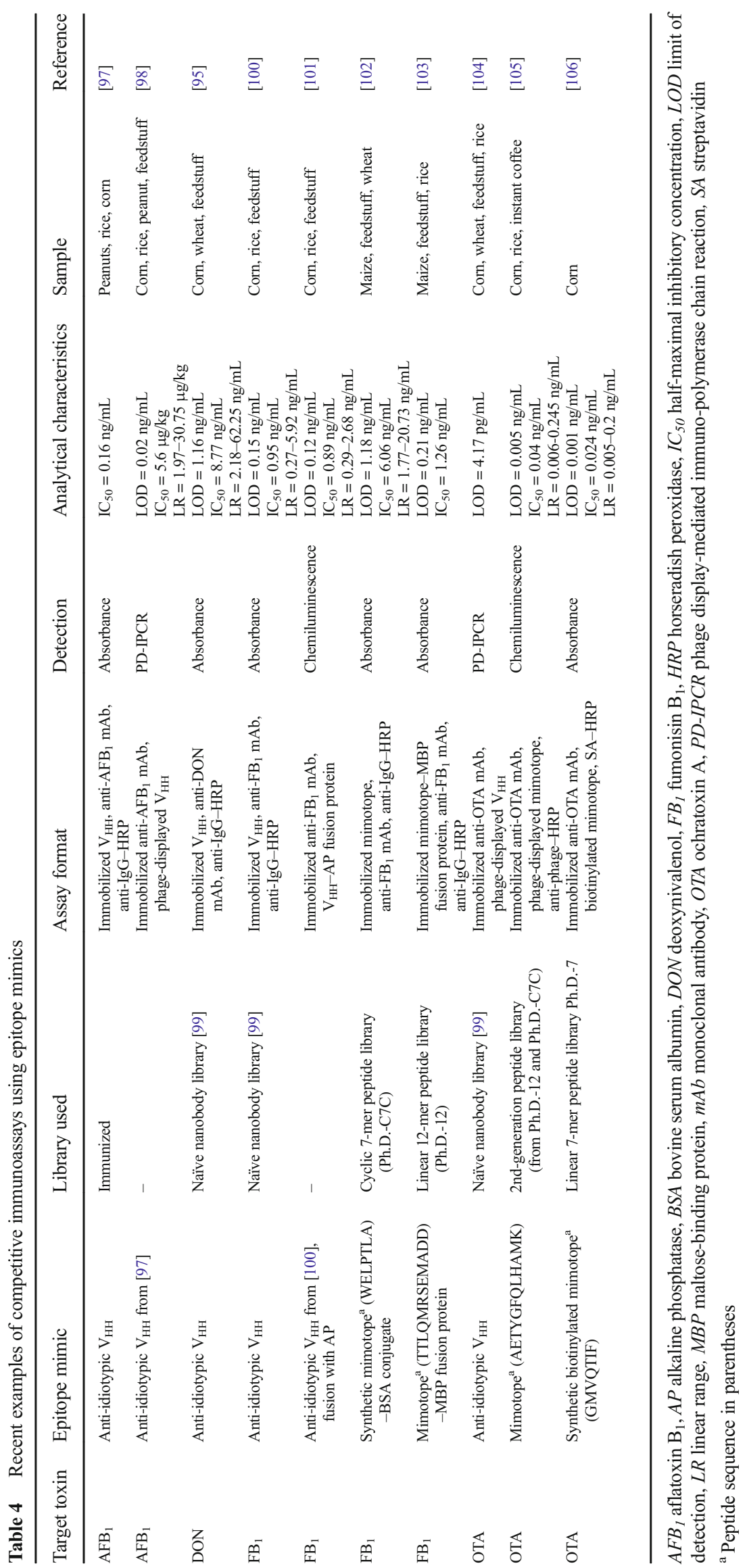


mimotopes [102] has been described. Although no clear consensus in the sequence of these mimotopes is seen, even with mimotopes for the same mycotoxin, the peptides usually contain several charged and aromatic amino acids. The use of mimotopes for mycotoxin detection has been described in several applications, and some recent examples are presented in Table 4. The phage-borne peptides have been directly used in ELISA with colorimetric [118] and chemiluminescent [105] detection, as well as in dipstick [105] and dot [121] immunoassays. Moreover, researchers have developed alternative "phage-free" approaches by replacing the phage-borne peptide with the synthetic or recombinant counterpart, thus avoiding the use of the phage in the assay. As the chemical synthesis of short peptides is a well-established and widely used method, the use of synthetic mimotopes is a simple alternative to use of the phage-displayed peptides. Such phage-free applications have been reported for OTA with use of a biotinylated mimotope with streptavidin-labeled horseradish peroxidase [106] as well as for $\mathrm{FB}_{1}$ with use of the synthetic peptide-bovine serum albumin conjugate as the coating antigen in peptide ELISA [102] and recently with use of a biotinylated mimotope in a microarray format (Fig. 3b) [93]. Alternatively, recombinant mimotopes can be expressed in E. coli as protein fusions and used to coat the ELISA plate without the need for further conjugation. For example, mimotopes for $\mathrm{OTA}$ and $\mathrm{FB}_{1}$ were fused with maltose-binding protein, and after purification the recombinant fusion proteins were directly used as coating agents in ELISA $[103,120]$. This approach can offer a cheaper alternative to the synthetic peptides as even large amounts of the fusion protein can be expressed in bacteria cost-effectively; however, the process requires cloning of the construct, which can be time-consuming.

\section{Peptides}

Peptides are involved in a wide range biochemical processes and are essential for many biological functions, such as signaling, cell growth, and metabolism [122]. As peptides share the same chemical structure as proteins, they can be considered as an attractive bioinspired recognition element to replace antibodies. Small peptides are stable in a wide range of conditions and are easy to synthesize, optionally with different modifications or tags for immobilization or labeling [123, 124]. Modeling of short peptides is relatively easy, and for screening, both molecular biology and chemical techniques are available [125]. Furthermore, peptide binders can be obtained also for targets that are difficult for antibodies, such as toxic molecules or targets with low immunogenicity [41]. Yet, only a few peptides have been successfully used as recognition elements since the design of new peptide receptors with high affinities is challenging because of limited understanding of interactions involved in the molecular recognition [126].
Peptides can be derived from natural sources (e.g. naturally occurring peptide hormones), from genetic or recombinant libraries, or from chemical libraries. They can be selected from combinatorial libraries that have been synthesized directly from the monomeric components, in the case of peptides from amino acids. As chemical synthesis has access to a wider diversity of the starting components, combinatorial libraries can be constructed with the use of not only natural but also unnatural amino acids or pseudo-peptide bonds [126]. The advances in bioinformatics and computational methods have also made it possible to design peptide receptors in silico. Molecular modeling can be used to obtain structural information about the target molecule that can then be applied to direct the design of combinatorial libraries, or to completely rationally design artificial receptors [126]. Alternatively, peptides can be selected from phage-displayed libraries that are based on phage vectors for displaying peptides as a fusion with one of the phage coat proteins [59]. The advantage of phage display technology is the fully random nature of the libraries, which do not contain rationally designed structures, and the same library can be used essentially for any target [125]. However, so far all the reported phage-displayed peptides for mycotoxin analysis have been used as mimotopes (see "Epitope mimics") rather than as the primary recognition element.

The few examples of peptide-based recognition of mycotoxins found in the literature include, for example, the development OTA-binding peptide NFO4, which was derived from a specific region of human oxidoreductase. Synthetic NFO4 was used with horseradish peroxidase conjugated OTA in a competitive ELISA which showed an $\mathrm{IC}_{50}$ of $3.2 \mu \mathrm{g} / \mathrm{L}$ [127]. Later the detection limit was slightly reduced by immobilization of the peptide on three-dimensional porous chitosan supports instead of a microtiter plate well [128] or by use of an amperometric sensor as the transducer [129]. Also Heurich et al. [130] designed an OTA-binding peptide, this time by computational modeling. In SPR analysis these de novo designed peptides showed binding toward OTA-bovine serum albumin conjugate with $K_{\mathrm{D}}$ of $11.8-15.7 \mu \mathrm{M}$; however, competitive assay with free OTA was not tested. Some groups have also identified peptides against OTA [131] and aflatoxins [132] by combinatorial synthesis. These peptides showed decent affinities for the mycotoxins, $K_{\text {eq }}=10^{3}-10^{4} \mathrm{M}^{-1}$, which was sufficient to retain the target in solution, and the chemically synthesized peptides could be used for solid-phase extraction of the toxins; however, such low affinity constants are usually not suitable for sensor development.

\section{Aptamers}

The etymological meaning of "aptamer" refers to the Latin word for "to fit", aptus, suggesting the relationship between aptamers and their target following the "lock-and-key" theory. 
Aptamers are small (usually from 2 to 60 nucleotides) singlestranded RNA or DNA that can bind specifically to diverse targets, including ions, peptides, proteins, cells, antibodies, and organic molecules. In a similar way, aptazymes (RNAzymes and DNAzymes) are engineered aptamers with allosteric properties that combine a target-binder strand and an enzyme strand. Aptamers for specific targets can be obtained by the screening of oligonucleotide libraries $\left(10^{14}-10^{15}\right.$ variants) through the process of systematic evolution of ligands by exponential enrichment (SELEX). Since the invention of SELEX more than 25 years ago, the method has evolved considerably. For example, most aptamers selected for small molecules until 2007 consisted of RNA, but in recent years, use of DNA aptamers has increased, given their stability to nuclease digestion [133]. In addition, the SELEX process has evolved to a variety of modified approaches that allow selection of aptamers with better specificity and binding efficiency (Fig. 4) [134]. New aptamer-related data are published almost every day, and thus online databases are available to provide access to, for example, specific aptamer applications or classification. An interesting example is the website http://www. aptagen.com/aptamer-index/aptamer-list.aspx.

Biosensors using aptamers as biorecognition elements, also referred as "aptasensors," were first described in 1996 [133-135], and have since been used in various sensing applications. Aptamers can provide high stability and affinity, as well as simplicity, low cost and excellent batch-to-batch reproducibility. Particularly, aptasensors have attracted huge attention in the analyses of food contaminants, such as mycotoxins, owing to the inherent advantages compared with other biorecognition elements, especially their excellent binding constants for most mycotoxins studied, with dissociation constants $\left(K_{\mathrm{D}}\right)$ in the nanomolar range (Table 5). Nonetheless, aptamers, especially RNA aptamers, are highly sensitive to nucleases, and moreover, aptamer affinity is strongly dependent on the binding conditions.

Immobilization of aptamers is a key step in the design of biosensors as it can affect the affinity of the aptamer for its target and also its long-term stability for real sample analysis. In recent years (2012-2017), mostly all immobilization strategies used for aptasensor development were based on (1) adsorption or $\pi-\pi$ stacking interactions between the DNA bases of the aptamer and graphene oxide (GO)-modified interfaces [140], (2) covalent linkage of the aptamer to carboxylic acid groups present on a surface or nanomaterial [145], (3) binding of thiolated aptamers to CdTe quantum dots (QDs) or Aubased materials [146], (4) affinity binding based on biotinstreptavidin or other affinity interactions [147, 148], or (5) hybridization to a partially complementary single-stranded DNA, previously immobilized on a surface or a nanoparticle [149-151].

In the same way as immunosensors, aptasensors have been used in several different sensing schemes to transduce the recognition process, such as direct, competitive, displacement,

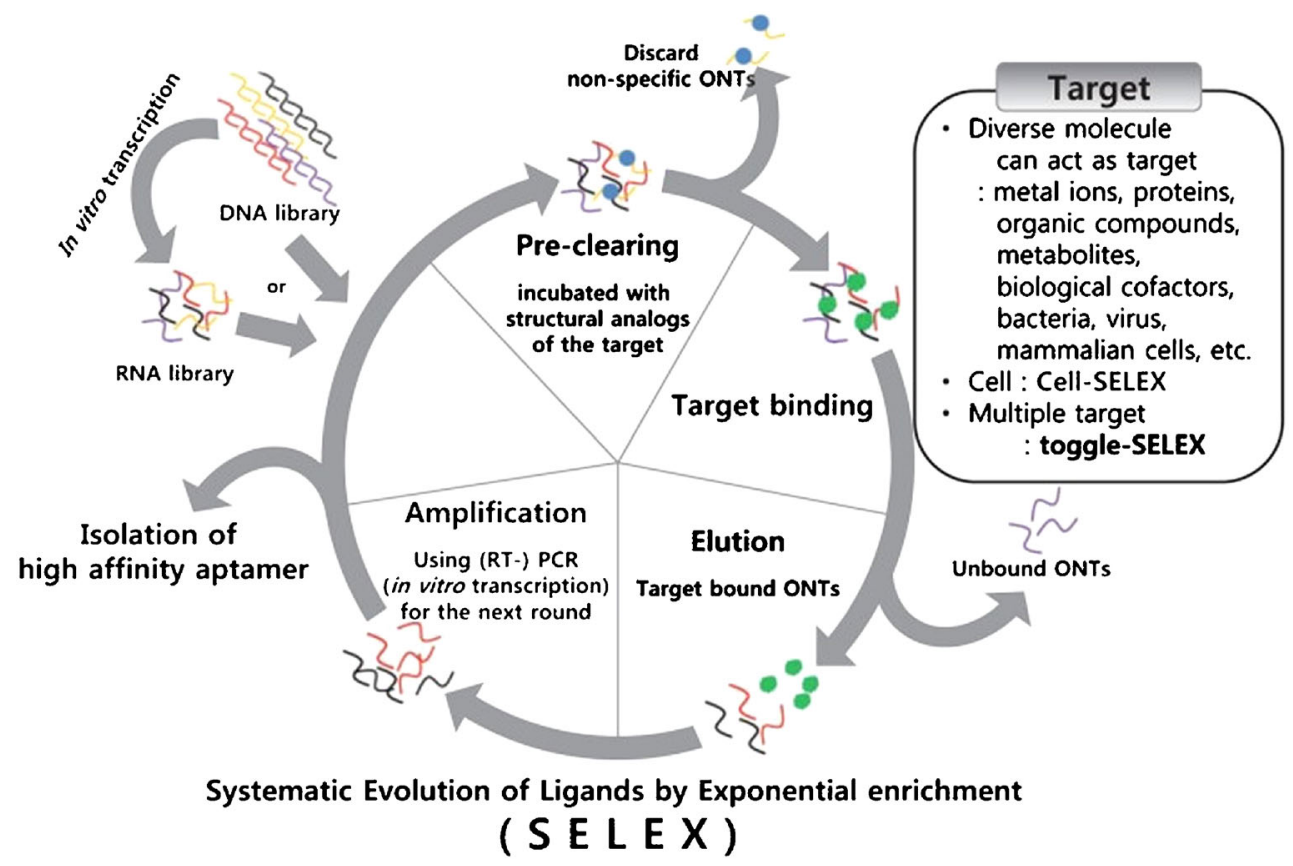

Fig. 4 In the systematic evolution of ligands by exponential enrichment (SELEX) process, an initial pool of $10^{14}-10^{15}$ random single-stranded DNA or RNA molecules is subjected to binding with the target, and the eluted probes are amplified by polymerase chain reaction (PCR). The selection process is repeated 6-15 times with amplified oligonucleotides (ONTs) as the new pool. Different SELEX modifications can be performed to obtain aptamers with high specificity and affinity; for example, toggle-SELEX can perform selections with two different target molecules to obtain bispecific aptamers. RT reverse transcription. (Reproduced with permission from [134], copyright 2013, Korean Society of Applied Pharmacology) 
Table 5 Dissociation constants $\left(K_{\mathrm{D}}\right)$ of some aptamers selective for mycotoxins

\begin{tabular}{|c|c|c|c|c|c|}
\hline Target toxin & $K_{\mathrm{D}}(\mathrm{nM})$ & $\begin{array}{l}\text { Aptamer } \\
\text { type }\end{array}$ & Binding conditions/buffer & $\begin{array}{l}\text { Length/ } \\
\text { CG } \\
\text { content }\end{array}$ & Reference \\
\hline $\mathrm{AFB}_{1}$ & 11.39 & DNA & $\begin{array}{l}\mathrm{pH} 7.0,100 \mathrm{mM} \mathrm{NaCl}^{2} 2 \mathrm{mM} \text { Tris- } \mathrm{HCl} \mathrm{pH} \text { 7.6, } \\
2 \mathrm{mM} \mathrm{MgCl} \mathrm{MgCl}_{2}, 5 \mathrm{mM} \mathrm{KCl}, 1 \mathrm{mM} \mathrm{CaCl}, 0.02 \% \\
\text { Tween } 20\end{array}$ & $80 / 55.0 \%$ & {$[136]$} \\
\hline $\mathrm{AFB}_{2}$ & 9.83 & DNA & 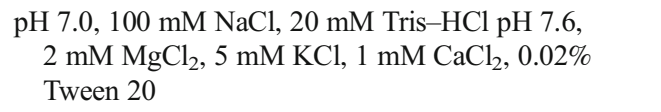 & $80 / 56 \%$ & {$[137]$} \\
\hline $\mathrm{AFM}_{1}$ & 0.0182 & DNA & NS & $21 / 38.1 \%$ & [138] \\
\hline Ergot alkaloid & 44 & DNA & $\begin{array}{l}100 \mathrm{mM} \mathrm{NaCl}, 20 \mathrm{mM} \text { Tris- } \mathrm{HCl} \mathrm{pH} \text { 7.6, } 5 \mathrm{mM} \mathrm{KCl}, \\
2 \mathrm{mM} \mathrm{MgCl}_{2}, 1 \mathrm{mM} \mathrm{CaCl}_{2}\end{array}$ & $80 / 62.5 \%$ & [139] \\
\hline $\mathrm{FB}_{1}$ & 100 & DNA & $\begin{array}{l}100 \mathrm{mM} \mathrm{NaCl}_{2} 20 \mathrm{mM} \text { Tris, } 2 \mathrm{mM} \mathrm{MgCl}, 5 \mathrm{mM} \mathrm{KCl} \text {, } \\
1 \mathrm{mM} \mathrm{CaCl}_{2} \text {, pH } 7.6\end{array}$ & $96 / 33.3 \%$ & {$[140]$} \\
\hline $\mathrm{FB}_{2}$ & ND & DNA & NS & $80 / 55 \%$ & {$[141]$} \\
\hline OTA & 96 & DNA & PBS $1 \times, 1 \mathrm{mM} \mathrm{MgCl} 2,0.01 \%$ Tween $20, \mathrm{pH} 7.4$ & $66 / 63.6 \%$ & {$[142]$} \\
\hline $\mathrm{T}-2$ toxin & 20.8 & DNA & $\begin{array}{l}10 \mathrm{mM} \text { Tris- } \mathrm{HCl}, 150 \mathrm{mM} \mathrm{NaCl}, 10 \mathrm{mM} \mathrm{KCl}, \\
2.5 \mathrm{mM} \mathrm{MgCl}_{2}, \mathrm{pH} 7.4\end{array}$ & $40 / 45.0 \%$ & [143] \\
\hline ZEN & 40 & DNA & $\begin{array}{l}\mathrm{pH} \text { 7.4, } 100 \mathrm{mM} \mathrm{NaCl}, 20 \mathrm{mM} \text { Tris- } \mathrm{HCl}, 2 \mathrm{mM} \\
\mathrm{MgCl}_{2}, 5 \mathrm{mM} \mathrm{KCl}, 1 \mathrm{mM} \mathrm{CaCl}_{2}, 0.02 \% \text { Tween } 20\end{array}$ & $40 / 50 \%$ & [144] \\
\hline
\end{tabular}

$A F B_{1}$ aflatoxin $\mathrm{B}_{1}, A F B_{2}$ aflatoxin $\mathrm{B}_{2}, A F M_{1}$ aflatoxin $\mathrm{M}_{1}, F B_{1}$ fumonisin $\mathrm{B}_{1}, F B_{2}$ fumonisin $\mathrm{B}_{2}, N S$ not stated, $O T A$ ochratoxin A, $P B S$ phosphatebuffered saline, Tris tris(hydroxymethyl)aminomethane, ZEN zearalenone

and sandwich assay formats [152]. In recent years, a wide variety of novel methods in combination with new transduction approaches or innovative amplification techniques (Fig. 5) have been reported $[153,154]$. For example, isothermal amplification of nucleic acids has emerged as a promising alternative for aptasensors [154]. Indeed, there are an increasing number of biosensors for a wide spectrum of targets (small molecules, ions, proteins, etc.) that have increased their sensitivity by incorporation of the isothermal amplification detection mode [155].

Some examples of recently reported aptasensors for mycotoxin detection are described in Table 6 . More than $40 \%$ of the mycotoxin aptasensors reported in the last couple of years are based on fluorescence, and among them, one of the most used strategies is based on the use of metal and carbon nanostructures, such as gold nanoparticles (AuNPs), GO, single-walled carbon nanotubes, $\mathrm{MoS}_{2}$ flakes, or $\mathrm{TiO}_{2}$ tubes. Many of these examples make use of the strong quenching of fluorescent aptamer conjugates adsorbed on these surfaces by $\pi-\pi$ stacking interactions [158-160]. For example, Lv et al. [160] fabricated a sensitive aptasensor for OTA detection using singlewalled carbon nanohorns (SWCNHs) as efficient quenchers, which provided complete loss of fluorescence intensity of the unfolded fluorescein (FAM)-labeled OTA-aptamer when absorbed onto the carbon nanohorn. Addition of OTA resulted in an aptamer shape change to a G-quadruplex that was further released from the SWCNH surface, with a corresponding increase in the fluorescence, proportional to the toxin concentration. The approach included a self-amplifying cycle that took advantage of the ability of DNase I to digest the released aptamer bound to OTA, liberating the free toxin, which could rebind a new aptamer adsorbed onto the SWCNHs. With this strategy, the sensitivity of the assay was increased 20 -fold compared with the unamplified approach, with a detection limit of $9.8 \mathrm{nM}$.

In a similar way, Zhang et al. [161] proposed an aptasensor for the detection of $\mathrm{AFB}_{1}$ using the same amplification system based on DNase I. In this case, three different sizes of nanoGOs were used to adsorb carboxyl-X-rhodamine (ROX) labeled $\mathrm{AFB}_{1}$ aptamer, acting as ROX quenchers but also as scaffolds to protect the aptamer from nuclease cleavage (Fig. 6a). Different dynamic ranges were obtained depending on the graphene sizes; GO with a size of $1000-2000 \mathrm{~nm}$ had a dynamic range from 12.5 to $312.5 \mathrm{ng} / \mathrm{mL}$, GO with a size of 60-80 nm had a dynamic range from 1.0 to $100 \mathrm{ng} / \mathrm{mL}$, and GO with a size of 4-6 $\mathrm{nm}$ had a dynamic range from 5.0 to 50 $\mathrm{ng} / \mathrm{mL}$. The sensor proved to be highly selective when tested against other mycotoxins, and good results were obtained with the aptasensor in $\mathrm{AFB}_{1}$-spiked corn samples.

Dai et al. [163] developed a luminescence resonance energy transfer assay using core-shell $\beta-\mathrm{NaYF}_{4}: \mathrm{Yb}$,Er@ $\mathrm{NaYF}_{4}$ upconverting nanoparticles coated with avidin, which binds to a biotinylated OTA aptamer, as energy donors and GO acting as an energy acceptor. A dynamic range from 0.001 to $250 \mathrm{ng} /$ $\mathrm{mL}$ was reported for OTA, and the assay showed good specificity toward the toxin in analysis of beer samples.

Although fluorescence-based methods can provide increased sensitivity, colorimetric methods usually profit from simplicity while maintaining the required sensitivity. The 
Fig. 5 Some examples of sensing schemes for optical aptasensors using fluorescent reporters or gold nanoparticles (GNPs). a

Quenching aptamer beacon. b

Fluorescence resonance energy transfer aptamer beacon. $\mathbf{c}$

Assembly aptamer beacon. d

Disassembly aptamer beacon. e

Aptamer release and GNP aggregation. $\mathbf{f}-\mathbf{g}$ Affinitymediated aggregation/ disaggregation. $\mathrm{F}$ fluorophore, $\mathrm{F}_{\mathrm{A}}$ acceptor fluorophore, $\mathrm{F}_{\mathrm{D}}$ donor fluorophore, Q quencher. (Adapted from [153])

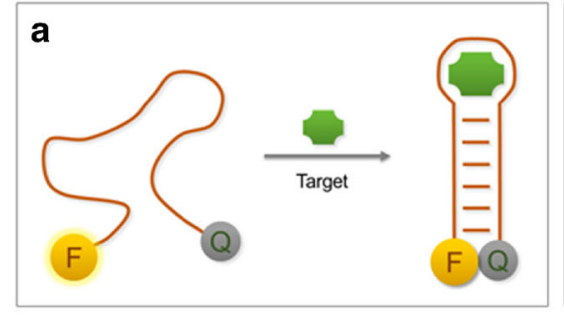

b
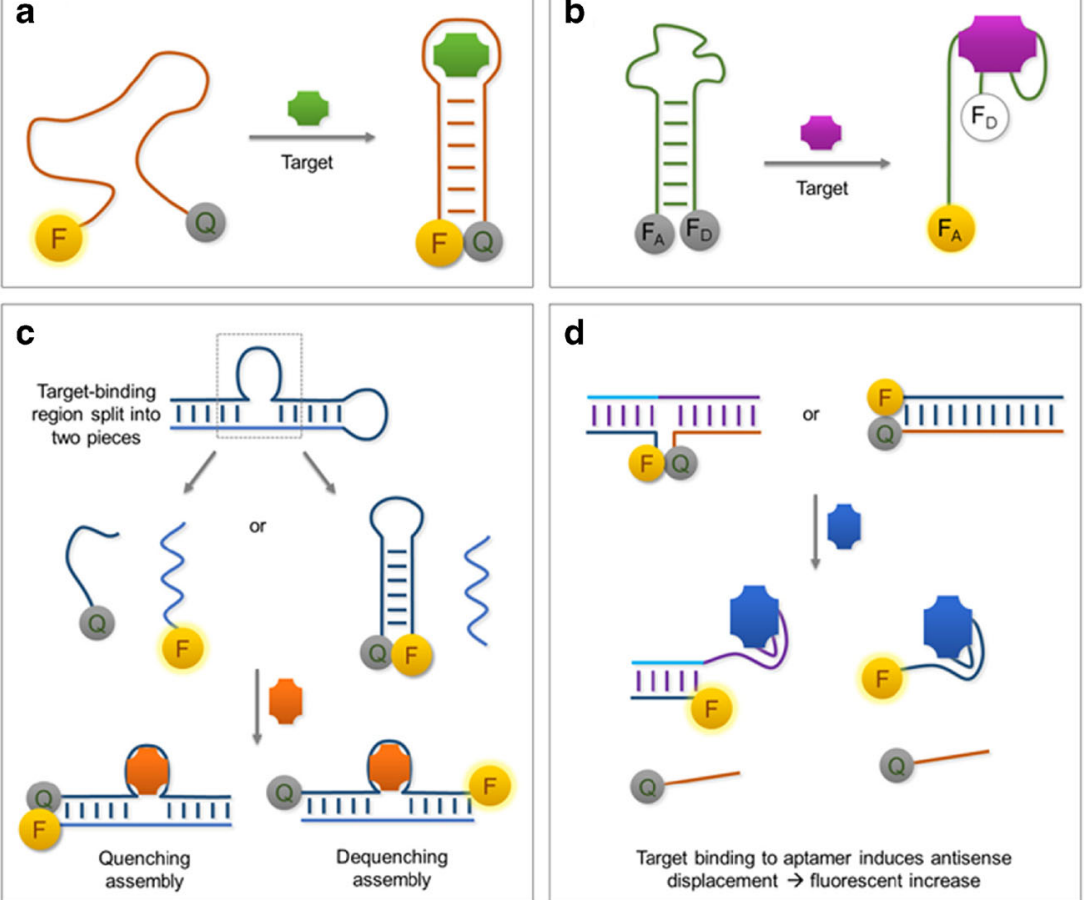

d
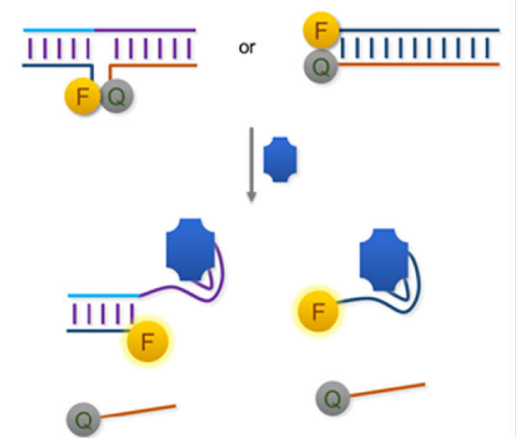

Target binding to aptamer induces antisense displacement $\rightarrow$ fluorescent increase
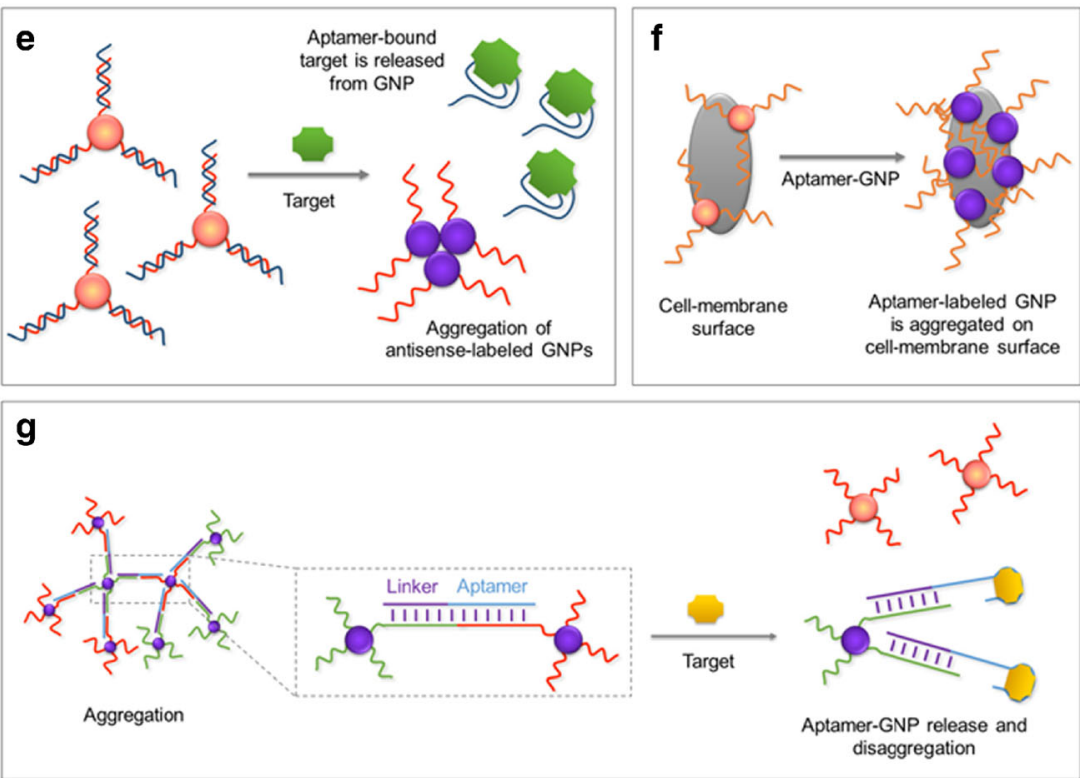

detection mechanism of widely used AuNPs is based on their remarkably high extinction coefficient and their strong color dependence on aggregation/disaggregation. Recently, several authors have reported innovative color-based detection systems that integrate AuNPs with aptamers for mycotoxin analysis [164]. For example, Chen et al. [162] reported an aptasensor for the detection of $\mathrm{AFB}_{1}$ based on a catalytic DNA circuit and AuNPs. The signal amplification was done without enzymes and was based in a toehold-mediated DNA strand displacement that occurred at room temperature [165]. The design strategy for the $\mathrm{AFB}_{1}$ aptasensor is illustrated in Fig. 6b. The $\mathrm{AFB}_{1}$ aptamer, included in $\mathrm{T}$, was partially hybridized with a complementary DNA (cDNA) (B in Fig. 6b) that cages the toehold domain ( $a^{*}$ in Fig. 6b). When the toxin is present, $\mathrm{a}^{*}$ is liberated, and the amplification process is activated. It involves the sequential opening of the three biotinylated hairpins ( $\mathrm{H} 1, \mathrm{H} 2$, and $\mathrm{H} 3)$, and thus the freeing of the toehold domains H1-b*, H2-c*, and H3-a*. Then, a branch migration is initiated to form a T-H1-H2-H3 complex that is unstable, and $\mathrm{T}$ dissociates, triggering the hybridization of additional hairpins. In parallel, the triplex $\mathrm{H} 1-\mathrm{H} 2-\mathrm{H} 3$ products interact with AuNP-streptavidin conjugates to form a cross-linked network of highly aggregated AuNPs. The blue color obtained because of the redshifting can be visualized 


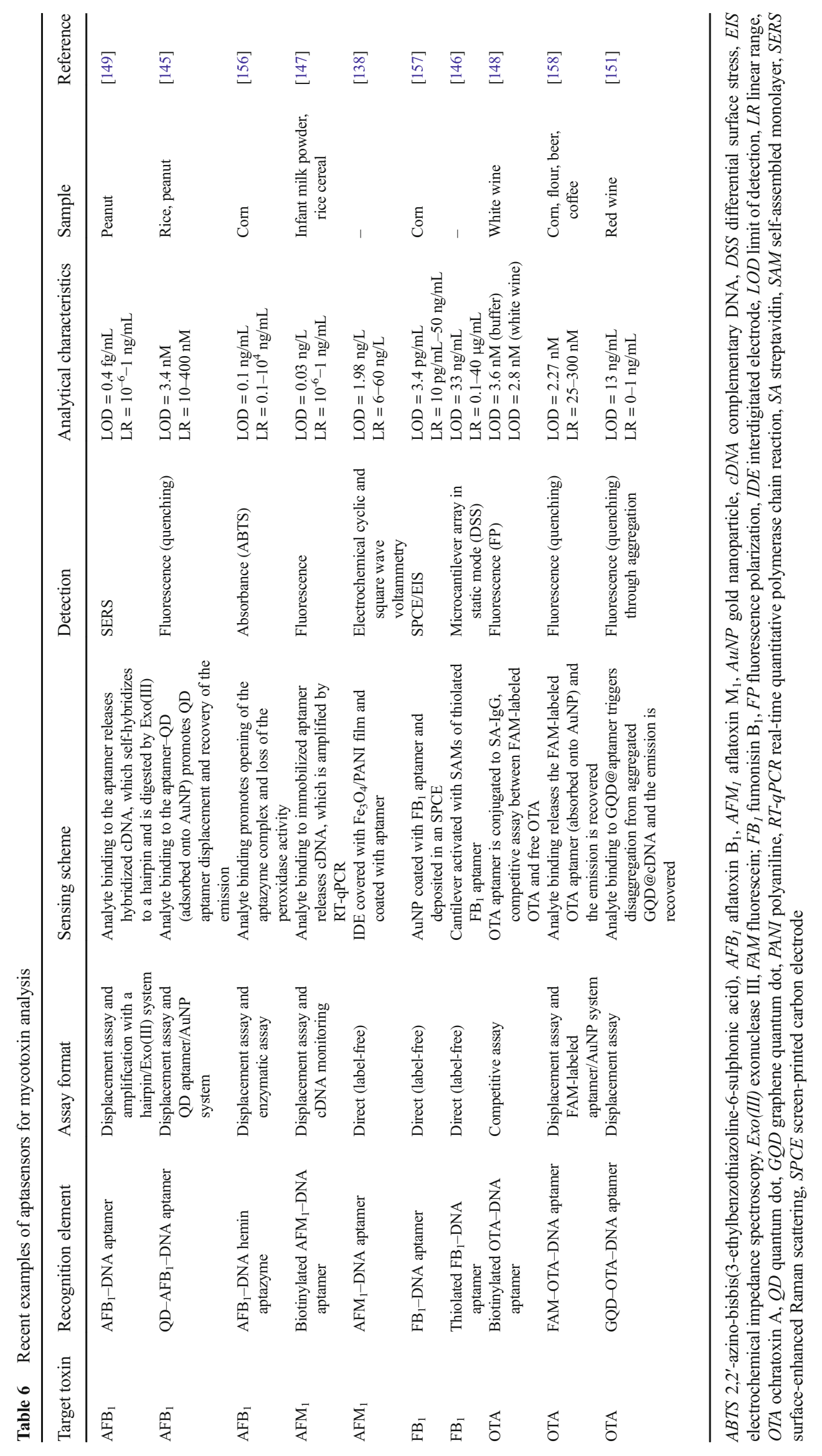




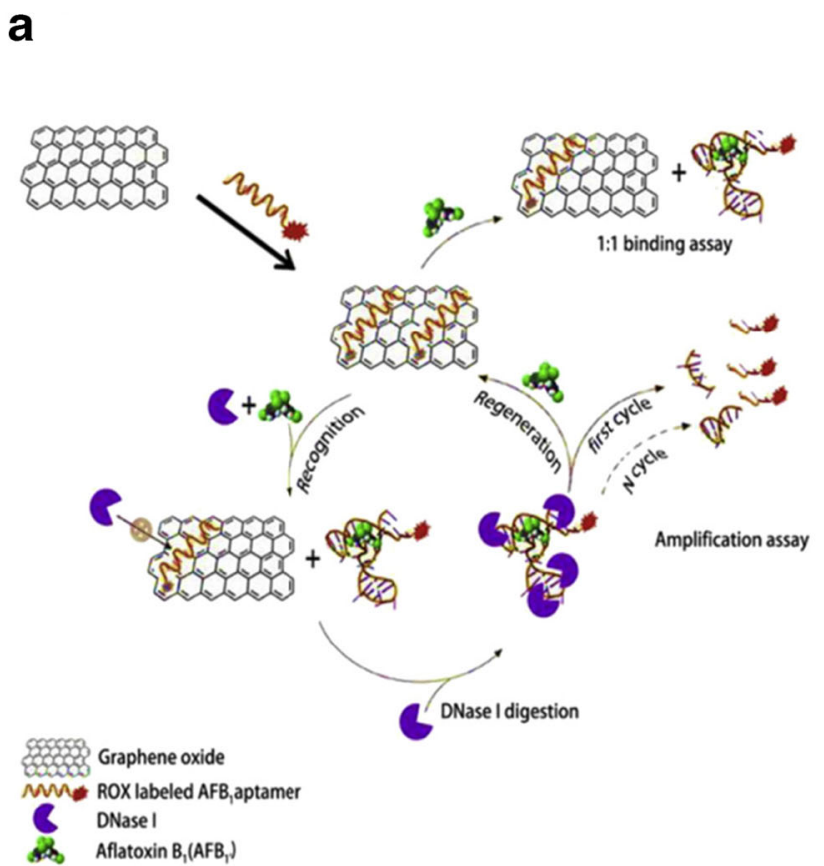

Fig. 6 a Detection of aflatoxin $\mathrm{B} 1\left(\mathrm{AFB}_{1}\right)$ using a DNA aptamer and graphene oxide. Each $\mathrm{AFB}_{1}$ aptamer binds to only a single $\mathrm{AFB}_{1}$ molecule and the complex is released from the graphene oxide surface. For amplification assay, the $\mathrm{AFB}_{1}$ is regenerated by a self-amplifying cycle based on DNase I. b Design strategy for amplified detection of $\mathrm{AFB}_{1}$ based on a catalytic DNA circuit and gold nanoparticles. Biotinylated hairpins $(\mathrm{H} 1, \mathrm{H} 2$, and $\mathrm{H} 3)$ are used in the sensing system

with the naked eye, allowing the quantification of $\mathrm{AFB}_{1}$. The limit of detection was $2 \mathrm{pM}$, and the aptasensor performance was validated by the analysis of the mycotoxin in rice samples, with recoveries ranging from $90 \%$ to $112 \%$.

Several mycotoxin aptasensors have also been described that use electrochemical detection, which has some particular advantages, including low cost, high sensitivity, or possibility of microfabrication. For example, Huang et al. [166] described an electrochemical aptasensor based on signal enhancement with a rolling circle amplification (RCA) system. The designed primer was composed of an aptamer sequence, selective for OTA, and a cDNA sequence, complementary to the capture probe immobilized on the gold electrode surface. In the absence of OTA, the aptamer-cDNA primer was partially hybridized to the template padlock and, under RCA conditions, its size increased exponentially. Moreover, it was also enriched in guanine nucleotides, where the redox probe methylene blue bound specifically and produced a significant signal enhancement in the differential pulse voltammetry. In the presence of OTA, the aptamer-cDNA primer was released from the RCA padlock to bind the mycotoxin. This induced inhibition of primer prolongation under the RCA system, yielding a reduction of the redox signal. The resulting b

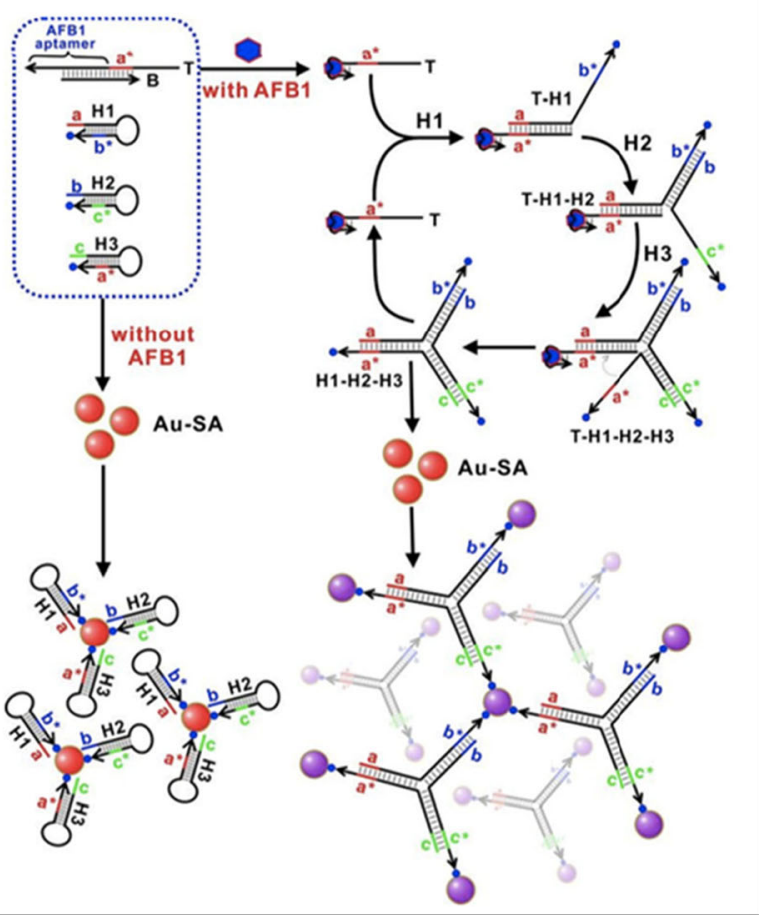

for signal amplification and streptavidin-functionalized gold nanoparticles (Au-SA) are used as colorimetric probes. Arrows drawn on DNA strands represent the 3 ' end. Toeholds and toehold binding domains are named by letters and complementarity is denoted by asterisks. ROX carboxyl-X-rhodamine. (a Reproduced from [161] with permission of the Royal Society of Chemistry; b reproduced from [162] with permission of the Royal Society of Chemistry)

electrochemical aptasensor could detect OTA with a detection limit of $0.065 \mathrm{pg} / \mathrm{mL}$, and was applied to the analysis of white wine samples, showing recoveries in the range of $102-104 \%$.

SPR is a label-free technique based on refractive index changes of a dielectric material at the metal-dielectric interface. Biosensors based on SPR are widely used for mycotoxin analysis because of their great features such as sensitivity and real-time, label-free, and cost-effective detection [47]. Recent efforts have focused on the development of portable and miniaturized SPR devices. For example, Bianco et al. [167] developed a plasmonic portable aptasensor for OTA detection based on azimuthally controlled SPR under phase interrogation [168]. The system had a refractive index one order of magnitude greater than that of the classic grating-based SPR setup. The label-free assay format was simple: a thiolated DNA aptamer was immobilized on the phase-interrogation SPR chip, forming self-assembled monolayers, and the signal was proportional to the amount of OTA bound to it. The aptasensor was operative in a dynamic range from 0.2 to 40 $\mathrm{ng} / \mathrm{mL}$ and exhibited a detection limit of $0.005 \mathrm{ng} / \mathrm{mL}$. Bianco et al. suggested that this custom approach could be implemented soon in a miniaturized device while maintaining its excellent analytical characteristics. 


\section{Molecularly imprinted polymers}

MIPs have shown a great potential as bioinspired recognition elements for sensor development. These artificial materials are able to recognize a particular target in complex mixtures because of the presence of specific recognition sites, for binding or catalysis, with shape and geometry of the functional groups complementary to those in the template molecule. For polymer preparation the template molecule, namely, the target analyte or a surrogate molecule, interacts by covalent or noncovalent bonding with the functional monomers. Radical polymerization in the presence of a cross-linker results in a three-dimensional network that on template removal will contain specific recognition cavities with size, geometry, and arrangement of functional groups complementary to those of the target compound, thus mimicking the biological activity of natural receptors. Template extraction is critical for application of MIPs as recognition elements in sensors. Bleeding of the non-washed-out template can cause false positives, inaccuracies in the analysis, and increased limits of quantification. The use of a template surrogate instead of the target compound may avoid this limitation; however, it will not prevent the decrease in the binding capacity of the MIP if its extraction from the binding sites is not quantitative [169].

Over the years MIPs have been applied in various fields, including solid-phase extraction, chromatography, drug delivery, bioremediation, controlled release, and sensors [170-177]. MIPs are often described as artificial antibodies or artificial enzymes [178], and in comparison with their biological counterparts they show several advantages as sensor receptors, including, but not limited to, their high physical and chemical stability, robustness, compatibility with organic solvents, low cost, ease of preparation, reusability, and availability in different physical formats for coupling to the transducer [179]. However, their affinity and specificity are typically worse than for antibodies, and the imprinted cavities are usually heterogeneous, showing a distribution of binding constants, and slower binding kinetics than biological receptors. In contrast to biological receptors, in some cases they show limited recognition in aqueous solutions, although extensive research in recent years has allowed some of the aforementioned shortcomings to be overcome [180]. Recent advances in the development of nanosized MIPs, alone or in combination with metal nanoparticles, have opened new perspectives in the application of these materials for sensing purposes, given that, among other advantages, they allow higher binding capacities, faster binding kinetics, and easier coupling to the transducer surface than traditional MIPs [175].

Several examples of the application of MIP-based sensors for mycotoxin detection have been reported in the last 5 years (Table 7). The website http://www.MIPdatabase.com collects all the information related to this topic. For example, $\mathrm{AFB}_{1}$ was detected with use of MIP films prepared by electropolymerization of $p$-aminothiophenol-functionalized AuNPs and $p$-aminothiophenol self-assembled on the surface of a gold electrode in the presence of the toxin as the template molecule. Recognition was attributed to the formation of $\pi-\pi$ interactions between $\mathrm{AFB}_{1}$ and the aniline moieties in the imprinted material. The response was linear in the range of $3.2 \mathrm{f}$. to $3.2 \mu \mathrm{M} \mathrm{AFB}$, and the device showed some crossreactivity with OTA, but this was very low for aflatoxin $B_{2}$ or aflatoxin $\mathrm{G}_{1}$ [181]. Higher detection limits $\left(3 \times 10^{-11} \mathrm{~mol} / \mathrm{L}\right)$ have been reported with electrochemical sensors fabricated with $o$-phenylenediamine as the functional monomer and $\mathrm{AFB}_{1}$ as the template on multiwalled carbon nanotube supported $\mathrm{Au} / \mathrm{Pt}$ bimetallic nanoparticle modified glassy carbon electrodes (GCEs) [182].

Several sensors have also been described that use QDs as the labels for mycotoxin detection; however, some limitations related to QD leaching, retention of the photoluminescent properties of the semiconductor on immobilization, and analyte permeation must be taken into consideration to develop stable and sensitive devices. A fluorescent sensor for the detection of sterigmatocystin (ST), a secondary metabolite produced by several Aspergillus species, that used silica-based hybrid MIPs based on the nonhydrolytic sol-gel method was reported [189]. The organosilane-functionalized QDs were coated with the imprinted polymer prepared with methacrylic acid (MAA) as the functional monomer, $\gamma$ methacryloxypropyltrimethoxysilane as the cross-linker, and 1,8-dihydroxyanthraquinone as the toxin surrogate. The luminescent properties of the QDs were not affected by encapsulation, and they showed excellent stability against photobleaching; however, the response times were relatively long $(4 \mathrm{~h})$. The measuring mechanism was based on the retention of the mycotoxin, through hydrogen bonding, in the selective cavities of the polymer, which resulted in electron transfer from QDs in the MIP matrix to the bound ST, with the corresponding quenching of the luminescence. The sensor showed some cross-reactivity for OTA, ZEN, and AFB ${ }_{1}$, and it was successfully applied to the analysis of ST in millet, rice, and maize samples.

A different approach was described for the detection of ZEN that used ionic-liquid-stabilized CdSe/ZnS QDs [190]. The polymers were prepared with cyclododecanyl-2,4dihydroxybenzoate as the template surrogate [191] and MAA as the functional monomer. The sensing mechanism relied on a charge-transfer mechanism between the conduction band of the QD and the lowest unoccupied molecular orbital of ZEN. The sensor was applied to the detection of the toxin in corn, wheat, and rice samples, with recoveries higher than $84.4 \%$, and showed no cross-reactivity with OTA or DON.

Patulin has been detected with a Mn-doped ZnS QD based nanosensor synthesized with 6-hydroxynicotinic acid as the surrogate, 3-aminopropyltriethoxysilane, as the functional 


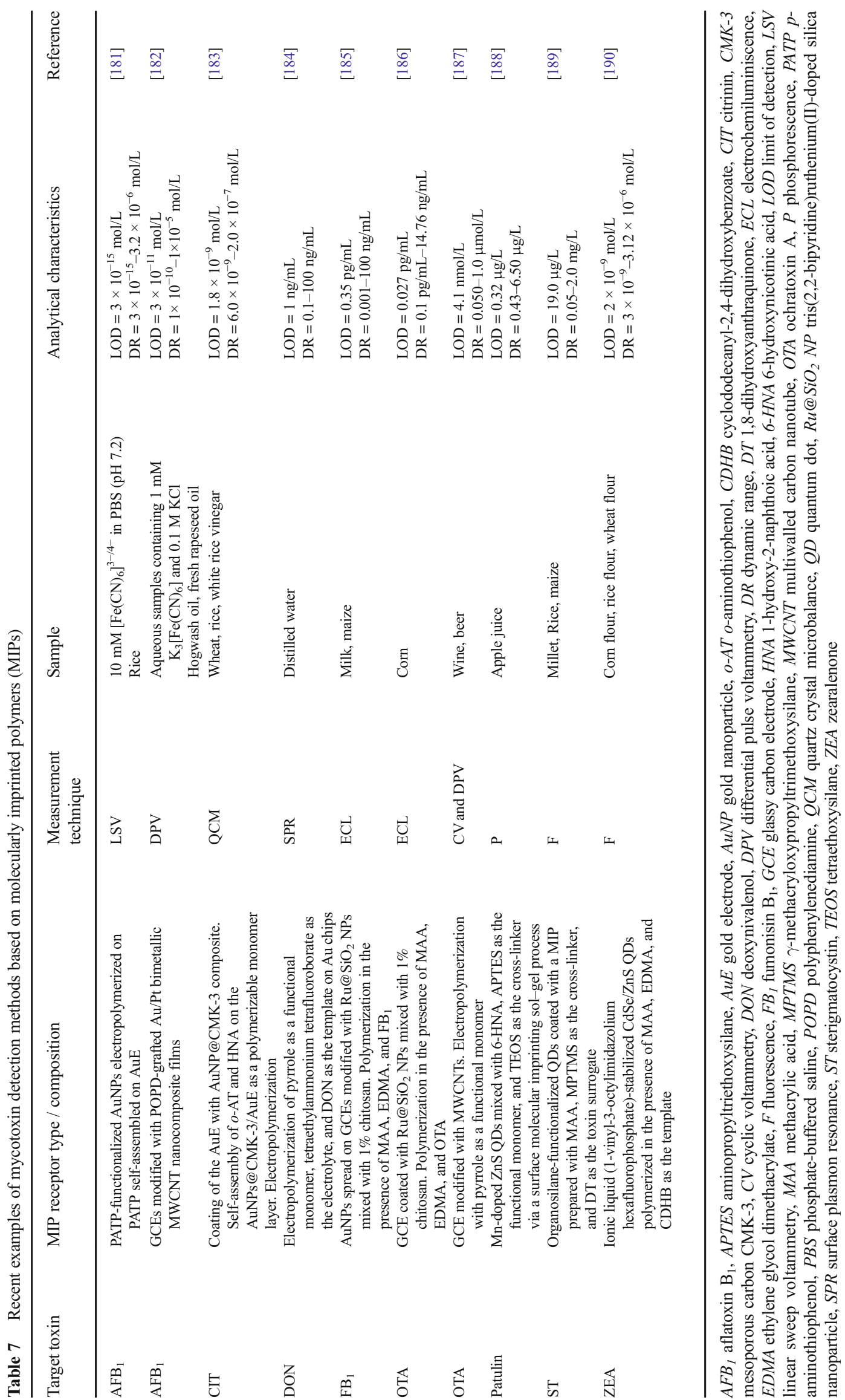


monomer, and tetraethoxysilane as the cross-linker via a surface molecular imprinting sol-gel process [188]. The MIPQDs showed strong phosphorescence that was quenched after 30 min incubation in the presence of the toxin. The sensing mechanism was based on photoinduced electron transfer from the conduction bands of MIP-QDs to the lowest unoccupied molecular orbital of patulin. The sensor was applied to the detection of the toxin in apple juice samples.

$\mathrm{FB}_{1}$ was monitored by electrochemiluminescence with use of GCEs coated with AuNPs to amplify the electrochemiluminescence signal, and further modified with a film formed by tris(2,2-bipyridine)ruthenium(II)-doped silica $\left(\mathrm{Ru} @ \mathrm{SiO}_{2}\right)$ nanoparticles mixed with chitosan [185]. The mycotoxin selective polymer, prepared with MAA as the functional monomer, was deposited on top and polymerized by UV irradiation. Signal enhancement in the MIP/Ru@ $@ \mathrm{SiO}_{2} /$ chitosan/AuNP/GCE system was attributed to a combination of both the localized SPR and electrochemical effect of the AuNPs.

CIT has been detected with disposable fiber optic sensors prepared from 4-cm-long injection-molded tapered polystyrene waveguides coated with CIT-imprinted particles (150$500 \mathrm{~nm}$ ) with polyvinyl alcohol used as a glue [192]. A fluorescent monomer, $N$-(2-(6-4-methylpiperazin-1-yl)-1,3dioxo-1 $H$-benzo[de]isoquinolin-2(3H)-yl-ethyl)acrylamide, was used for MIP synthesis. An enhancement of the fluorescence intensity of the signaling monomer was observed on $30 \mathrm{~min}$ incubation of the functionalized fiber in methanol solutions of the mycotoxin, and evanescent wave excitation at $410 \mathrm{~nm}$. The emitted light was guided back to the detector with use of the same fiber. In principle this approach could be extended to the detection of other mycotoxins bearing carboxylic acid groups, such as OTA or fumonisins, although the thickness of the MIP layer requires fine-tuning to increase the sensitivity.

In an alternative approach [183], CIT was detected with a quartz crystal microbalance. The Au electrode was coated with AuNP@mesoporous carbon CMK-3 (AuNP@CMK-3) and further modified a poly $(o$-aminothiophenol) MIP selective membrane. The increase in the number of binding sites associated with the use of AuNP@CMK-3 allowed amplification of the frequency response signal. The polymer showed a higher adsorption capacity for CIT in comparison with OTA, $\mathrm{DON}, \mathrm{AFB}_{1}$, or ZEA, and showed good performance for the analysis of rice, wheat, and white rice vinegar samples spiked with the mycotoxin in the range of $10-100 \mu \mathrm{g} \mathrm{kg}^{-1}$.

\section{Conclusions}

Despite the best intentions with regard to prevention, mycotoxin contamination is often inevitable. Novel analytical methods can improve the detection and quantification of the toxins and provide the necessary tools to ensure food safety; the use of sensors is an attractive alternative for sensitive, costeffective and fast analysis of these natural toxins. The recognition element selected for sensor development should ideally provide enough sensitivity and specificity to detect low amounts of the target toxins even in complex samples, where several different toxins can be present simultaneously. Moreover, from a practical point of view, robustness, stability, and cost can affect the choice of the recognition element. Although immunoassays and biosensors based on monoclonal and polyclonal antibodies have been the cornerstone of mycotoxin detection for years, slowly other recognition elements are beginning to appear, and recent research efforts have shown a great deal of interest in developing novel bioinspired recognition elements to overcome some of the drawbacks associated with conventional antibodies.

The rise of recombinant antibodies has been witnessed in several fields, including mycotoxin research, owing to the appealing features of antibody fragments, including small size, easy production, and the possibility of in vitro selection. Indeed, the technology has the potential to bypass animal immunization, although most of the reported recombinant antibodies for mycotoxins arose from monoclonal antibodies or immunized libraries. The vast possibilities offered by antibody and protein engineering allow the generation of different antibody formats, from the already well-known $\mathrm{scFv}$ to heterogeneous protein fusions or anti-immune complex antibodies. The widely hyped antibody class, heavy chain antibody, and its recombinant fragment $\mathrm{V}_{\mathrm{HH}}$, or nanobody, have also been noted in the field of mycotoxin analysis. Because of the limitation of nanobodies to recognize hapten targets, most of the nanobodies reported so far have been applied as epitope mimics, which allow the problems related to the toxin conjugates used in competitive immunoassays to be circumvented. Several anti-idiotypic antibodies and peptides, mimotopes, have been described as well in recent years for mycotoxin detection with improved performance compared with the use of toxin conjugates.

On the other hand, aptamers can offer high affinity and specificity, comparable to those of antibodies, with good stability and robustness. Although several new aptasensors have been reported in the recent years, most of them targeting OTA or aflatoxins, a significant concern of researchers in the field is the development of complex architectures with costly amplification procedures that greatly limit their commercial boost. It is not only the achievement of exotic aptasensors that matters nowadays but also the development of inexpensive approaches and their application to real samples. MIPs, often described as artificial antibodies, have also been reported as attractive alternative recognition elements. MIPs have several advantages compared with their biological counterparts, but often are not able to compete in affinity and specificity. However, recent advances in the field have opened new opportunities, which will allow higher binding capacities and faster kinetics. 
It remains to be seen whether these bioinspired recognition elements are able to compete with conventional antibodies for mycotoxin sensor design. Replacement of monoclonal and polyclonal antibodies is unlikely, as well as unnecessary, but the bioinspired recognition elements could be a complementary option, rather than an alternative, as they can be more appropriate for some applications where the use of antibodies is limited. It is also noteworthy that the noble intention to improve analytical methods relies not only on the choice of the recognition element but also on the transduction (optical, electrochemical, etc.) and signal generation (labeled and labelfree) strategies as well as the assay platform. Novel materials can provide improvements in the assay robustness, and implementation of signal amplification strategies can have a huge impact on assay sensitivity. On the other hand, for example, for in-field applications, the time and cost of the analysis are constraints, and rapid methods are needed for mycotoxin detection. Currently such tests, for example, lateral flow assays and colorimetric ELISAs, are based on monoclonal antibodies, but the use of bioinspired recognition elements could offer some improvements, such as better stability and extended shelf life. Furthermore, as several mycotoxins are often present in the same food sample, multiplexing is a key point that should be studied. Integration of novel assay schemes, for example, on microfluidic chips or array platforms, shows great potential for multianalyte detection with affordable cost.

Acknowledgements This work was funded by the European Union (SAMOSS; FP7-PEOPLE-2013-ITN; contract 607590) and MINECO/ FEDER (CTQ2015-69278-C2-1-R).

\section{Compliance with ethical standards}

Conflict of interest The authors declare that they have no competing interests.

\section{References}

1. das Chagas Oliveira Freire F, Bereza da Rocha ME. Impact of mycotoxins on human health. In: Mérillon J-M, Ramawat KG, editors. Fungal metabolites. Cham: Springer; 2016. p. 269-1. https://doi.org/10.1007/978-3-319-19456-1_21-1.

2. Goyal S, Ramawat KG, Mérillon J-M. Different shades of fungal metabolites: An overview. In: Mérillon J-M, Ramawat KG, editors. Fungal metabolites. Cham: Springer; 2017. p. 1-29. https:// doi.org/10.1007/978-3-319-25001-4_34.

3. Bennett JW, Klich M. Mycotoxins. Clin Microbiol Rev. 2003;16: 497-516.

4. Pitt JI, Miller JD. A concise history of mycotoxin research. J Agric Food Chem. 2016; https://doi.org/10.1021/acs.jafc.6b04494.

5. Turner NW, Subrahmanyam S, Piletsky SA. Analytical methods for determination of mycotoxins: a review. Anal Chim Acta. 2009;632:168-80. https://doi.org/10.1016/j.aca.2008.11.010.

6. Yu J, Payne GA, Campbell BC, Guo B, Cleveland TE, Robens JF, et al. Mycotoxin production and prevention of aflatoxin contamination in food and feed. In: Goldman GH, Osmani SA, editors.
The Aspergilli: genomics, medical aspects, biotechnology, and research methods. Boca Raton: CRC Press; 2007. p. 457-72. https://doi.org/10.1201/9781420008517.ch27.

7. Wilson D, Williams JT, Wild C, Stroka J, Shephard G, Schaafsma $\mathrm{A}$, et al. Public health strategies for reducing aflatoxin exposure in developing countries: a workgroup report. Environ Health Perspect. 2006; https://doi.org/10.1289/ehp.9302.

8. Peraica M, Radić B, Lucić A, Pavlović M. Toxic effects of mycotoxins in humans. Bull World Health Organ. 1999;77:754-66.

9. Bailly JD, Guerre P. Mycotoxin analysis in poultry and processed meats. In: Nollet LML, Toldrá F, editors. Safety analysis of foods of animal origin. Boca Raton: CRC Press; 2010. p. 77-123.

10. Berthiller F, Crews C, Dall'Asta C, De Saeger S, Haesaert G, Karlovsky P, Oswald IP, Seefelder W, Speijers G, Stroka J. Masked mycotoxins: a review. Mol Nutr Food Res 2013;57: 165-186. doi:https://doi.org/10.1002/mnfr.201100764.

11. European Commission. Commission Regulation (EC) No 1881/2006. Off J Eur Union. 2006;L364:5-24.

12. European Commission. Commission Regulation (EC) No 1126/2007. Off J Eur Union. 2007;L255:14-7.

13. European Commission. Commission Recommendation (EC) No 165/2013. Off J Eur Union. 2013;L91:12-5.

14. European Commission. Commission Regulation (EC) No 105/ 2010. Off J Eur Union. 2010;L35:7-8.

15. European Commission. Commission Regulation (EC) No 165/ 2010. Off J Eur Union. 2010;L50:8-12.

16. European Commission. Commission Directive (EC) No 32/2002/ EC. 2002.

17. European Commission. Commission Recommendation (EC) No 576/2006. Off J Eur Union. 2006;L229:7-10.

18. Berthiller F, Brera C, Crews C, Iha MH, Krska R, Lattanzio VMT, et al. Developments in mycotoxin analysis: an update for 2014 2015. World Mycotoxin J. 2016;9:5-30. https://doi.org/10.3920/ wmj2015.1998.

19. Bryla M, Roszko M, Szymczyk K, Jedrzejczak R, Obiedzinski MW, Sekul J. Fumonisins in plant-origin food and fodder - a review. Food Addit Contam Part A. 2013;30:1626-40. https:// doi.org/10.1080/19440049.2013.809624.

20. Senyuva HZ, Gilbert J, Stroka J. Determination of fumonisins $B_{1}$ and $\mathrm{B}_{2}$ in corn by LC/MS with immunoaffinity column cleanup: Interlaboratory study. J AOAC Int. 2010;93:611-21.

21. Solfrizzo M, De Girolamo A, Gambacorta L, Visconti A, Stroka J, van Egmond HP. Determination of fumonisins $B_{1}$ and $B_{2}$ in cornbased foods for infants and young children by LC with immunoaffinity column cleanup: Interlaboratory validation study. J AOAC Int 2011;94:900-908.

22. Goryacheva IY, De Saeger S, Eremin SA, Van Peteghem C. Immunochemical methods for rapid mycotoxin detection: evolution from single to multiple analyte screening: a review. Food Addit Contam 2007;24:1169-1183. doi:https://doi.org/10.1080/ 02652030701557179 .

23. Köppen R, Koch M, Siegel D, Merkel S, Maul R, Nehls I. Determination of mycotoxins in foods: Current state of analytical methods and limitations. Appl Microbiol Biotechnol. 2010;86: 1595-612. https://doi.org/10.1007/s00253-010-2535-1.

24. Zourob M. Recognition receptors in biosensors. New York: Springer; 2010.

25. Skottrup PD. Small biomolecular scaffolds for improved biosensor performance. Anal Biochem. 2010;406:1-7. https://doi.org/ 10.1016/j.ab.2010.06.042.

26. Wild D. The immunoassay handbook: theory and applications of ligand binding, ELISA and related techniques. 4th ed. Oxford: Elsevier; 2013.

27. Byrne B, Stack E, Gilmartin N, O'Kennedy R. Antibody-based sensors: principles, problems and potential for detection of 
pathogens and associated toxins. Sensors (Basel). 2009;9:440745. https://doi.org/10.3390/s90604407.

28. Langone JJ, Van Vunakis H. Aflatoxin B; specific antibodies and their use in radioimmunoassay. J Natl Cancer Inst 1976;56:591-595.

29. Sun ZT. Monoclonal antibody against aflatoxin $B_{1}$ and its potential application. Zhonghua Zhong Liu Za Zhi. 1983;5:401-5.

30. Groopman JD, Trudel LJ, Donahue PR, Marshak-Rothstein A, Wogan GN. High-affinity monoclonal antibodies for aflatoxins and their application to solid-phase immunoassays. Proc Natl Acad Sci U S A. 1984;81:7728-31.

31. Vidal JC, Bertolín JR, Ezquerra A, Hernández S, Castillo JR. Rapid simultaneous extraction and magnetic particle-based enzyme immunoassay for the parallel determination of ochratoxin A, fumonisin $\mathrm{B}_{1}$ and deoxynivalenol mycotoxins in cereal samples. Anal Methods. 2017;9:3602-11. https://doi.org/10.1039/ c7ay00386b.

32. Kong W, Xiao C, Ying G, Liu X, Zhao X, Wang R, et al. Magnetic microspheres-based cytometric bead array assay for highly sensitive detection of ochratoxin A. Biosens Bioelectron. 2017;94:420 8. https://doi.org/10.1016/j.bios.2017.03.025.

33. Urusov AE, Petrakova AV, Vozniak MV, Zherdev AV, Dzantiev BB. Rapid immunoenzyme assay of aflatoxin $B_{1}$ using magnetic nanoparticles. Sensors (Basel). 2014;14:21843-57. https://doi. org/10.3390/s141121843.

34. Beloglazova NV, Speranskaya ES, Wu A, Wang Z, Sanders M, Goftman VV, Zhang D, Goryacheva IY, De Saeger S. Novel multiplex fluorescent immunoassays based on quantum dot nanolabels for mycotoxins determination. Biosens Bioelectron 2014;62:59-65. doi:https://doi.org/10.1016/j.bios.2014.06.021.

35. Li C, Wen K, Mi T, Zhang X, Zhang H, Zhang S, et al. A universal multi-wavelength fluorescence polarization immunoassay for multiplexed detection of mycotoxins in maize. Biosens Bioelectron. 2016;79:258-65. https://doi.org/10.1016/j.bios.2015.12.033.

36. Wu S, Duan N, Zhu C, Ma X, Wang M, Wang Z. Magnetic nanobead-based immunoassay for the simultaneous detection of aflatoxin $\mathrm{B}_{1}$ and ochratoxin $\mathrm{A}$ using upconversion nanoparticles as multicolor labels. Biosens Bioelectron. 2011;30:35-42. https:// doi.org/10.1016/j.bios.2011.08.023.

37. Karczmarczyk A, Dubiak-Szepietowska M, Vorobii M, Rodriguez-Emmenegger C, Dostalek J, Feller KH. Sensitive and rapid detection of aflatoxin $\mathrm{M}_{1}$ in milk utilizing enhanced SPR and p(HEMA) brushes. Biosens Bioelectron. 2016;81:159-65. https://doi.org/10.1016/j.bios.2016.02.061.

38. Joshi S, Segarra-Fas A, Peters J, Zuilhof H, van Beek TA, Nielen MW. Multiplex surface plasmon resonance biosensing and its transferability towards imaging nanoplasmonics for detection of mycotoxins in barley. Analyst 2016;141:1307-1318. doi:https:// doi.org/10.1039/c5an02512e.

39. Ricciardi C, Castagna R, Ferrante I, Frascella F, Marasso SL, Ricci A, et al. Development of a microcantilever-based immunosensing method for mycotoxin detection. Biosens Bioelectron. 2013;40: 233-9. https://doi.org/10.1016/j.bios.2012.07.029.

40. Ma H, Sun J, Zhang Y, Bian C, Xia S, Zhen T. Label-free immunosensor based on one-step electrodeposition of chitosangold nanoparticles biocompatible film on $\mathrm{Au}$ microelectrode for determination of aflatoxin $\mathrm{B}_{1}$ in maize. Biosens Bioelectron. 2016;80:222-9. https://doi.org/10.1016/j.bios.2016.01.063.

41. Bazin I, Tria SA, Hayat A, Marty JL. New biorecognition molecules in biosensors for the detection of toxins. Biosens Bioelectron. 2017;87:285-98. https://doi.org/10.1016/j.bios.2016.06.083.

42. Shephard GS. Current status of mycotoxin analysis: a critical review. J AOAC Int. 2016;99:842-8. https://doi.org/10.5740/ jaoacint.16-0111.

43. Bradbury AR, Sidhu S, Dubel S, McCafferty J. Beyond natural antibodies: the power of in vitro display technologies. Nat Biotechnol. 2011;29:245-54. https://doi.org/10.1038/nbt.1791.
44. Tangni EK, Motte JC, Callebaut A, Pussemier L. Cross-reactivity of antibodies in some commercial deoxynivalenol test kits against some fusariotoxins. J Agric Food Chem. 2010;58:12625-33. https://doi.org/10.1021/jf103025e.

45. Zachariasova M, Hajslova J, Kostelanska M, Poustka J, Krplova A, Cuhra P, et al. Deoxynivalenol and its conjugates in beer: A critical assessment of data obtained by enzyme-linked immunosorbent assay and liquid chromatography coupled to tandem mass spectrometry. Anal Chim Acta. 2008;625:77-86. https://doi.org/ 10.1016/j.aca.2008.07.014.

46. Janeway CA, Travers P, Walport M, Shlomchik MJ. Immunobiology: the immune system in health and disease. 5th ed. New York: Garland Science; 2001.

47. Peltomaa R, López-Perolio I, Benito-Peña E, Barderas R, MorenoBondi MC. Application of bacteriophages in sensor development. Anal Bioanal Chem. 2016;408:1805-28. https://doi.org/10.1007/ s00216-015-9087-2.

48. Vincke C, Muyldermans S. Introduction to heavy chain antibodies and derived nanobodies. Methods Mol Biol. 2012;911:15-26. https://doi.org/10.1007/978-1-61779-968-6_2.

49. Holliger P, Hudson PJ. Engineered antibody fragments and the rise of single domains. Nat Biotechnol. 2005;23:1126-36. https://doi. org/10.1038/nbt1142.

50. Charlton KA. Expression and isolation of recombinant antibody fragments in E. coli. In: Lo BKC, editor. Antibody engineering: methods and protocols. Totowa: Humana; 2004. p. 245-54. https://doi.org/10.1385/1-59259-666-5:245.

51. Romanazzo D, Ricci F, Volpe G, Elliott CT, Vesco S, Kroeger K, Moscone D, Stroka J, Van Egmond H, Vehniainen M, Palleschi G. Development of a recombinant Fab-fragment based electrochemical immunosensor for deoxynivalenol detection in food samples. Biosens Bioelectron 2010;25:2615-2621. doi:https://doi.org/10. 1016/j.bios.2010.04.029.

52. Min W-K, Kweon D-H, Park K, Park Y-C, Seo J-H. Characterisation of monoclonal antibody against aflatoxin $\mathrm{B}_{1}$ produced in hybridoma $2 \mathrm{C} 12$ and its single-chain variable fragment expressed in recombinant Escherichia coli. Food Chem. 2011;126:1316-23. https://doi.org/10.1016/j.foodchem.2010.11. 088.

53. Maragos CM, Li L, Chen D. Production and characterization of a single chain variable fragment $(\mathrm{scFv})$ against the mycotoxin deoxynivalenol. Food Agric Immunol. 2012;23:51-67. https:// doi.org/10.1080/09540105.2011.598921.

54. Min WK, Cho YJ, Park JB, Bae YH, Kim EJ, Park K, et al. Production and characterization of monoclonal antibody and its recombinant single chain variable fragment specific for a foodborn mycotoxin, fumonisin $\mathrm{B}_{1}$. Bioprocess Biosyst Eng. 2010;33:109-15. https://doi.org/10.1007/s00449-009-0350-9.

55. Hu ZQ, Li HP, Wu P, Li YB, Zhou ZQ, Zhang JB, et al. An affinity improved single-chain antibody from phage display of a library derived from monoclonal antibodies detects fumonisins by immunoassay. Anal Chim Acta. 2015;867:74-82. https://doi.org/10. 1016/j.aca.2015.02.014.

56. Li X, Li P, Lei J, Zhang Q, Zhang W, Li C. A simple strategy to obtain ultra-sensitive single-chain fragment variable antibodies for aflatoxin detection. RSC Adv. 2013;3:22367. https://doi.org/10. 1039/c3ra42706d.

57. Hoogenboom HR. Selecting and screening recombinant antibody libraries. Nat Biotechnol. 2005;23:1105-16. https://doi.org/10. 1038/nbt1126.

58. McCafferty J, Griffiths AD, Winter G, Chiswell DJ. Phage antibodies: filamentous phage displaying antibody variable domains. Nature. 1990;348:552-4. https://doi.org/10.1038/348552a0.

59. Barbas CF, Burton DR, Silverman GJ. Phage display: a laboratory manual. Cold Spring Harbor: Cold Spring Harbor Press; 2001. 
60. Boder ET, Wittrup KD. Yeast surface display for screening combinatorial polypeptide libraries. Nat Biotechnol. 1997;15:553-7. https://doi.org/10.1038/nbt0697-553.

61. Hanes J, Pluckthun A. In vitro selection and evolution of functional proteins by using ribosome display. Proc Natl Acad Sci U S A. 1997;94:4937-42.

62. Levin AM, Weiss GA. Optimizing the affinity and specificity of proteins with molecular display. Mol BioSyst. 2006;2:49-57. https://doi.org/10.1039/b511782h.

63. Huse WD, Sastry L, Iverson SA, Kang AS, Alting-Mees $\mathrm{M}$, Burton DR, et al. Generation of a large combinatorial library of the immunoglobulin repertoire in phage lambda. Science. 1989;246:1275-81.

64. Hu Z-Q, Li H-P, Liu J-L, Xue S, Gong A-D, Zhang J-B, et al. Production of a phage-displayed mouse $\mathrm{ScFv}$ antibody against fumonisin $\mathrm{B}_{1}$ and molecular docking analysis of their interactions. Biotechnol Bioprocess Eng. 2016;21:134-43. https://doi.org/10. 1007/s12257-015-0495-0.

65. Tullila A, Nevanen TK. Utilization of multi-immunization and multiple selection strategies for isolation of hapten-specific antibodies from recombinant antibody phage display libraries. Int $\mathrm{J}$ Mol Sci. 2017;18 https://doi.org/10.3390/ijms18061169.

66. Edupuganti SR, Edupuganti OP, O'Kennedy R. Generation of anti-zearalenone scFv and its incorporation into surface plasmon resonance-based assay for the detection of zearalenone in sorghum. Food Control. 2013;34:668-74. https://doi.org/10.1016/j. foodcont.2013.06.013.

67. Liu X, Xu Y, Xiong YH, Tu Z, Li YP, He ZY, et al. VHH phagebased competitive real-time immuno-polymerase chain reaction for ultrasensitive detection of ochratoxin A in cereal. Anal Chem. 2014;86:7471-7. https://doi.org/10.1021/ac501202d.

68. Vaughan TJ, Williams AJ, Pritchard K, Osbourn JK, Pope AR, Earnshaw JC, et al. Human antibodies with sub-nanomolar affinities isolated from a large non-immunized phage display library. Nat Biotechnol. 1996;3:309-14. https://doi.org/10.1038/nbt0396309.

69. Griffiths AD, Williams SC, Hartley O, Tomlinson IM, Waterhouse P, Crosby WL, et al. Isolation of high affinity human antibodies directly from large synthetic repertoires. EMBO J. 1994;13:3245-60.

70. Persson H, Lantto J, Ohlin M. A focused antibody library for improved hapten recognition. J Mol Biol. 2006;357:607-20. https://doi.org/10.1016/j.jmb.2006.01.004.

71. Lauer B, Ottleben I, Jacobsen HJ, Reinard T. Production of a single-chain variable fragment antibody against fumonisin $\mathrm{B}_{1}$. J Agric Food Chem. 2005;53:899-904. https://doi.org/10.1021/ jf048651s.

72. Yang L, Ding H, Gu Z, Zhao J, Chen H, Tian F, et al. Selection of single chain fragment variables with direct coating of aflatoxin $\mathrm{B}_{1}$ to enzyme-linked immunosorbent assay plates. J Agric Food Chem. 2009;57:8927-32. https://doi.org/10.1021/jf9019536.

73. Min WK, Kim SG, Seo JH. Affinity maturation of single-chain variable fragment specific for aflatoxin $\mathrm{B}_{1}$ using yeast surface display. Food Chem. 2015;188:604-11. https://doi.org/10.1016/j. foodchem.2015.04.117.

74. He T, Wang Y, Li P, Zhang Q, Lei J, Zhang Z, et al. Nanobodybased enzyme immunoassay for aflatoxin in agro-products with high tolerance to cosolvent methanol. Anal Chem. 2014;86:887380. https://doi.org/10.1021/ac502390c.

75. Liu X, Xu Y, Wan DB, Xiong YH, He ZY, Wang XX, et al. Development of a nanobody-alkaline phosphatase fusion protein and its application in a highly sensitive direct competitive fluorescence enzyme immunoassay for detection of ochratoxin A in cereal. Anal Chem. 2015;87:1387-94. https://doi.org/10.1021/ ac504305z.
76. Hamers-Casterman C, Atarhouch T, Muyldermans S, Robinson G, Hamers C, Songa EB, et al. Naturally occurring antibodies devoid of light chains. Nature. 1993;363:446-8.

77. Dumoulin M, Conrath K, Van Meirhaeghe A, Meersman F, Heremans K, Frenken LG, Muyldermans S, Wyns L, Matagne A. Single-domain antibody fragments with high conformational stability. Protein Sci 2002;11:500-515. doi:https://doi.org/10. 1110/ps.34602.

78. Liu X, Tang Z, Duan Z, He Z, Shu M, Wang X, et al. Nanobodybased enzyme immunoassay for ochratoxin A in cereal with high resistance to matrix interference. Talanta. 2017;164:154-8. https:// doi.org/10.1016/j.talanta.2016.11.039.

79. Sun Z, Duan Z, Liu X. Development of a nanobody-based competitive dot ELISA for visual screening of ochratoxin A in cereals. Food Anal Methods. 2017;1-7. doi:https://doi.org/10.1007/ s12161-017-0915-1.

80. Bever CS, Dong J-X, Vasylieva N, Barnych B, Cui Y, Xu Z-L, et al. $\mathrm{V}_{\mathrm{HH}}$ antibodies: emerging reagents for the analysis of environmental chemicals. Anal Bioanal Chem. 2016;408:5985-6002. https://doi.org/10.1007/s00216-016-9585-x.

81. de Marco A. Biotechnological applications of recombinant singledomain antibody fragments. Microb Cell Factories 2011;10:44. doi:https://doi.org/10.1186/1475-2859-10-44.

82. Jackson TM, Ekins RP. Theoretical limitations on immunoassay sensitivity: current practice and potential advantages of fluorescent $\mathrm{Eu}^{3+}$ chelates as non-radioisotopic tracers. J Immunol Methods. 1986;87:13-20. https://doi.org/10.1016/0022-1759(86)90338-8.

83. Ueda H, Tsumoto K, Kubota K, Suzuki E, Nagamune T, Nishimura $\mathrm{H}$, et al. Open sandwich ELISA: a novel immunoassay based on the interchain interaction of antibody variable region. Nat Biotechnol. 1996;14:1714-8. https://doi.org/10.1038/ nbt1296-1714.

84. Fan M, Jiang H. Recent progress in noncompetitive hapten immunoassays: a review. In: Abuelzein E, editor. Trends in immunolabelled and related techniques. Rijeka: In Tech; 2012. https://doi.org/10.5772/36688.

85. Li P, Deng S. Mimetic peptide and special antibody: promising agents for optimizing hapten-analyzing systems. Anal Methods. 2016;8:2554-60. https://doi.org/10.1039/c5ay02533h.

86. Suzuki T, Munakata Y, Morita K, Shinoda T, Ueda H. Sensitive detection of estrogenic mycotoxin zearalenone by open sandwich immunoassay. Anal Sci. 2007;1:65-70.

87. Ullman EF, Milburn G, Jelesko J, Radika K, Pirio M, Kempe T, et al. Anti-immune complex antibodies enhance affinity and specificity of primary antibodies. Proc Natl Acad Sci U S A. 1993;90: 1184-9.

88. Pulli T, Höyhtyä M, Söderlund H, Takkinen K. One-step homogeneous immunoassay for small analytes. Anal Chem. 2005;77: 2637-42. https://doi.org/10.1021/ac0483791.

89. González-Techera A, Vanrell L, Last JA, Hammock BD, González-Sapienza G. Phage anti-immune complex assay: general strategy for noncompetitive immunodetection of small molecules. Anal Chem. 2007;79:7799-806.

90. Kim H-J, McCoy M, Gee SJ, González-Sapienza GG, Hammock BD. Noncompetitive phage anti-immunocomplex real-time polymerase chain reaction for sensitive detection of small molecules. Anal Chem. 2011;83:246-53.

91. Arola HO, Tullila A, Kiljunen H, Campbell K, Siitari H, Nevanen TK. Specific noncompetitive immunoassay for HT-2 mycotoxin detection. Anal Chem. 2016;88:2446-52. https://doi.org/10.1021/ acs.analchem. 5 b04591.

92. Arola HO, Tullila A, Nathanail AV, Nevanen TK. A simple and specific noncompetitive ELISA method for HT-2 toxin detection. Toxins (Basel). 2017;9:-145. https://doi.org/10.3390/ toxins 9040145 . 
93. Peltomaa R, Benito-Peña E, Barderas R, Sauer U, Gonzalez Andrade M, Moreno-Bondi MC. Microarray-based immunoassay with synthetic mimotopes for the detection of fumonisin $\mathrm{B}_{1}$. Anal Chem. 2017;89:6216-23. https://doi.org/10.1021/acs.analchem. $7 \mathrm{~b} 01178$.

94. Chauhan R, Singh J, Sachdev T, Basu T, Malhotra BD. Recent advances in mycotoxins detection. Biosens Bioelectron. 2016;81: 532-45. https://doi.org/10.1016/j.bios.2016.03.004.

95. Qiu YL, He QH, Xu Y, Bhunia AK, Tu Z, Chen B, et al. Deoxynivalenol-mimic nanobody isolated from a naïve phage display nanobody library and its application in immunoassay. Anal Chim Acta. 2015;887:201-8. https://doi.org/10.1016/j.aca. 2015.06.033.

96. Xiao H, Clarke JR, Marquardt RR, Frohlich AA. Improved methods for conjugating selected mycotoxins to carrier proteins and dextran for immunoassays. J Agric Food Chem. 1995;43: 2092-7. https://doi.org/10.1021/jf00056a025.

97. Wang Y, Li P, Majkova Z, Bever CR, Kim HJ, Zhang Q, et al. Isolation of alpaca anti-idiotypic heavy-chain single-domain antibody for the aflatoxin immunoassay. Anal Chem. 2013;85:8298303. https://doi.org/10.1021/ac4015885.

98. Lei J, Li P, Zhang Q, Wang Y, Zhang Z, Ding X, et al. Antiidiotypic nanobody-phage based real-time immuno-PCR for detection of hepatocarcinogen aflatoxin in grains and feedstuffs. Anal Chem. 2014;86:10841-6. https://doi.org/10.1021/ ac5029424.

99. Tu Z, Xu Y, He Q, Fu J, Liu X, Tao Y. Isolation and characterisation of deoxynivalenol affinity binders from a phage display library based on single-domain camelid heavy chain antibodies $\left(\mathrm{V}_{\mathrm{HH}} \mathrm{s}\right)$. Food Agric Immunol. 2012;23:123-31. https://doi.org/ 10.1080/09540105.2011.606560.

100. Shu M, Xu Y, Wang D, Liu X, Li Y, He Q, et al. Anti-idiotypic nanobody: A strategy for development of sensitive and green immunoassay for fumonisin $\mathrm{B}_{1}$. Talanta. 2015;143:388-93. https:// doi.org/10.1016/j.talanta.2015.05.010.

101. Shu M, Xu Y, Liu X, Li Y, He Q, Tu Z, et al. Anti-idiotypic nanobody-alkaline phosphatase fusion proteins: development of a one-step competitive enzyme immunoassay for fumonisin $\mathrm{B}_{1}$ detection in cereal. Anal Chim Acta. 2016;924:53-9. https://doi. org/10.1016/j.aca.2016.03.053.

102. Liu X, Xu Y, He QH, He ZY, Xiong ZP. Application of mimotope peptides of fumonisin $\mathrm{B}_{1}$ in peptide ELISA. J Agric Food Chem. 2013;61:4765-70. https://doi.org/10.1021/jf400056p.

103. Xu Y, Chen B, He QH, Qiu YL, Liu X, He ZY, et al. New approach for development of sensitive and environmentally friendly immunoassay for mycotoxin fumonisin $\mathrm{B}_{1}$ based on using peptide-MBP fusion protein as substitute for coating antigen. Anal Chem. 2014;86:8433-40. https://doi.org/10.1021/ ac502037w.

104. Ji Y, He Q, Xu Y, Tu Z, Yang H, Qiu Y, et al. Phage displayed antiidiotypic nanobody mediated immuno-PCR for sensitive and environmentally friendly detection of mycotoxin ochratoxin A. Anal Methods. 2016;8:7824-31. https://doi.org/10.1039/c6ay01264g.

105. He ZY, He QH, Xu Y, Li YP, Liu X, Chen B, et al. Ochratoxin A mimotope from second-generation peptide library and its application in immunoassay. Anal Chem. 2013;85:10304-11. https://doi. org/10.1021/ac402127t.

106. Zou X, Chen C, Huang X, Chen X, Wang L, Xiong Y. Phage-free peptide ELISA for ochratoxin A detection based on biotinylated mimotope as a competing antigen. Talanta. 2016;146:394-400. https://doi.org/10.1016/j.talanta.2015.08.049.

107. Uner A, Gavalchin J. Idiotypes. Chichester: Wiley; 2006.

108. Hsu KH, Chu FS. Production and characterization of anti-idiotype and anti-anti-idiotype antibodies from a monoclonal antibody against aflatoxin. J Agric Food Chem. 1994;42:2353-9. https:// doi.org/10.1021/jf00046a052.
109. Guan D, Li P, Cui Y, Zhang Q, Zhang W. A competitive immunoassay with a surrogate calibrator curve for aflatoxin $\mathrm{M}_{1}$ in milk. Anal Chim Acta. 2011;703:64-9. https://doi.org/10.1016/j.aca. 2011.07.011.

110. Chu FS, Huang X, Maragos CM. Production and characterization of anti-idiotype and anti-anti-idiotype antibodies against fumonisin $B_{1}$. J Agric Food Chem. 1995;43:261-7. https://doi. org/10.1021/jf00049a046.

111. Maragos CM. Production of anti-idiotype antibodies for deoxynivalenol and their evaluation with three immunoassay platforms. Mycotoxin Res. 2014;30:103-11. https://doi.org/10.1007/ s12550-014-0190-6.

112. Yuan Q, Pestka JJ, Hespenheide BM, Kuhn LA, Linz JE, Hart LP. Identification of mimotope peptides which bind to the mycotoxin deoxynivalenol-specific monoclonal antibody. Appl Environ Microbiol. 1999;65:3279-86.

113. Chanh T, Rappocciolo G, Hewetson J. Monoclonal anti-idiotype induces protection against the cytotoxicity of the trichothecene mycotoxin T-2. J Immunol. 1990;144:4721-8.

114. Chanh T, Siwak E, Hewetson J. Anti-idiotype-based vaccines against biological toxins. Toxicol Appl Pharmacol. 1991;108: 183-93.

115. Wang D, Xu Y, Tu Z, Fu JH, Xiong YH, Feng F, et al. Isolation and characterization of recombinant variable domain of heavy chain anti-idiotypic antibodies specific to aflatoxin $\mathrm{B}_{1}$. Biomed Environ Sci. 2014;27:118-21. https://doi.org/10.3967/bes2014.025.

116. Xu Y, Xiong L, Li Y, Xiong Y, Tu Z, Fu J, et al. Citrinin detection using phage-displayed anti-idiotypic single-domain antibody for antigen mimicry. Food Chem. 2015;177:97-101. https://oi.org/ 10.1016/j.foodchem.2015.01.007.

117. Xu Y, Xiong L, Li Y, Xiong Y, Tu Z, Fu J, et al. Anti-idiotypic nanobody as citrinin mimotope from a naive alpaca heavy chain single domain antibody library. Anal Bioanal Chem. 2015;407: 5333-41. https://doi.org/10.1007/s00216-015-8693-3.

118. Liu R, Yu Z, He Q, Xu Y. An immunoassay for ochratoxin A without the mycotoxin. Food Control. 2007;18:872-7. https:// doi.org/10.1016/j.foodcont.2006.05.002.

119. Lai W, Fung DYC, Yang X, Renrong L, Xiong Y. Development of a colloidal gold strip for rapid detection of ochratoxin A with mimotope peptide. Food Control. 2009;20:791-5. https://doi.org/ 10.1016/j.foodcont.2008.10.007.

120. Xu Y, He Z, He Q, Qiu Y, Chen B, Chen J, et al. Use of cloneable peptide-MBP fusion protein as a mimetic coating antigen in the standardized immunoassay for mycotoxin ochratoxin A. J Agric Food Chem. 2014;62:8830-6. https://doi.org/10.1021/jf5028922.

121. He Q-h, Xu Y, Zhang C-Z, Li Y-P, Huang Z-B. Phage-borne peptidomimetics as immunochemical reagent in dotimmunoassay for mycotoxin zearalenone. Food Control. 2014;39:56-61. https://doi.org/10.1016/j.foodcont.2013.10.019.

122. Nelson D, Cox ME. Lehninger principles of biochemistry. 4th ed. New York: Freeman; 2005.

123. Chen H, Huang J, Palaniappan A, Wang Y, Liedberg B, Platt M, et al. A review on electronic bio-sensing approaches based on nonantibody recognition elements. Analyst. 2016;141:2335-46. https://doi.org/10.1039/c5an02623g.

124. Liu Q, Wang J, Boyd BJ. Peptide-based biosensors. Talanta. 2015;136:114-27. https://doi.org/10.1016/j.talanta.2014.12.020.

125. Pavan S, Berti F. Short peptides as biosensor transducers. Anal Bioanal Chem. 2012;402:3055-70. https://doi.org/10.1007/ s00216-011-5589-8.

126. Tothill IE. Peptides as molecular receptors. In: Zourob M, editor. Recognition receptors in biosensors. New York: Springer; 2010. p. 249-74.

127. Bazin I, Andreotti N, Hassine AI, De Waard M, Sabatier JM, Gonzalez C. Peptide binding to ochratoxin A mycotoxin: a new 
approach in conception of biosensors. Biosens Bioelectron 2013;40:240-246. doi:https://doi.org/10.1016/j.bios.2012.07.031.

128. Soleri R, Demey H, Tria SA, Guiseppi-Elie A, Hassine AI, Gonzalez C, et al. Peptide conjugated chitosan foam as a novel approach for capture-purification and rapid detection of haptenexample of ochratoxin A. Biosens Bioelectron. 2015;67:634-41. https://doi.org/10.1016/j.bios.2014.09.084.

129. Tria SA, Lopez-Ferber D, Gonzalez C, Bazin I, Guiseppi-Elie A. Microfabricated biosensor for the simultaneous amperometric and luminescence detection and monitoring of ochratoxin A. Biosens Bioelectron. 2016;79:835-42. https://doi.org/10.1016/j.bios.2016. 01.018 .

130. Heurich M, Altintas Z, Tothill IE. Computational design of peptide ligands for ochratoxin A. Toxins. 2013;5:1202-18. https://doi. org/10.3390/toxins5061202.

131. Giraudi G, Ferrero VE, Anfossi L, Baggiani C, Giovannoli C, Tozzi C. Solid-phase extraction of ochratoxin A from wine based on a binding hexapeptide prepared by combinatorial synthesis. J Chromatogr A. 2007;1175:174-80. https://doi.org/10.1016/j. chroma.2007.10.057.

132. Tozzi C, Anfossi L, Baggiani C, Giovannoli C, Giraudi G. A combinatorial approach to obtain affinity media with binding properties towards the aflatoxins. Anal Bioanal Chem. 2003;375:994-9. https://doi.org/10.1007/s00216-003-1754-z.

133. Pfeiffer F, Mayer G. Selection and biosensor application of aptamers for small molecules. Front Chem. 2016;4:25. https:// doi.org/10.3389/fchem.2016.00025.

134. Kong HY, Byun J. Nucleic acid aptamers: new methods for selection, stabilization, and application in biomedical science. Biomol Ther. 2013;21:423-34. https://doi.org/10.4062/biomolther.2013. 085 .

135. Kleinjung F, Klussmann S, Erdmann VA, Scheller FW, Fürste JP, Bier FF. High-affinity RNA as a recognition element in a biosensor. Anal Chem. 1998;70:328-31. https://doi.org/10.1021/ ac9706483.

136. Ma X, Wang W, Chen X, Xia Y, Wu S, Duan N, et al. Selection, identification, and application of aflatoxin $\mathrm{B}_{1}$ aptamer. Eur Food Res Technol. 2014;238:919-25. https://doi.org/10.1007/s00217014-2176-1.

137. Ma X, Wang W, Chen X, Xia Y, Duan N, Wu S, et al. Selection, characterization and application of aptamers targeted to aflatoxin B $_{2}$. Food Control. 2015;47:545-51. https://doi.org/10.1016/j. foodcont.2014.07.037.

138. Nguyen BH, Tran LD, Do QP, Nguyen HL, Tran NH, Nguyen PX. Label-free detection of aflatoxin $\mathrm{M}_{1}$ with electrochemical $\mathrm{Fe}_{3} \mathrm{O}_{4} /$ polyaniline-based aptasensor. Mater Sci Eng C Mater Biol Appl. 2013;33:2229-34. https://doi.org/10.1016/j.msec.2013.01.044.

139. Rouah-Martin E, Mehta J, van Dorst B, de Saeger S, Dubruel P, Maes BU, Lemiere F, Goormaghtigh E, Daems D, Herrebout W, van Hove F, Blust R, Robbens J. Aptamer-based molecular recognition of lysergamine, metergoline and small ergot alkaloids. Int J Mol Sci 2012;13:17138-17159. doi:https://doi.org/10.3390/ ijms131217138.

140. McKeague M, Bradley CR, De Girolamo A, Visconti A, Miller JD, Derosa MC. Screening and initial binding assessment of fumonisin $B_{1}$ aptamers. Int $J$ Mol Sci 2010;11:4864-4881. doi: https://doi.org/10.3390/ijms11124864.

141. Wu S, Zhang L, Yang M Fumonisins $B_{2}$ nucleic acid aptamer and application thereof. 2012. Patent CN 102517290 A.

142. Barthelmebs L, Jonca J, Hayat A, Prieto-Simon B, Marty J-L. Enzyme-linked aptamer assays (ELAAs), based on a competition format for a rapid and sensitive detection of Ochratoxin A in wine. Food Control. 2011;22:737-43. https://doi.org/10.1016/j. foodcont.2010.11.005.

143. Chen X, Huang Y, Duan N, Wu S, Xia Y, Ma X, et al. Screening and identification of DNA aptamers against T-2 toxin assisted by graphene oxide. J Agric Food Chem. 2014;62:10368-74. https:// doi.org/10.1021/jf5032058.

144. Chen X, Huang Y, Duan N, Wu S, Ma X, Xia Y, et al. Selection and identification of ssDNA aptamers recognizing zearalenone. Anal Bioanal Chem. 2013;405:6573-81. https://doi.org/10.1007/ s00216-013-7085-9.

145. Sabet FS, Hosseini M, Khabbaz H, Dadmehr M, Ganjali MR. FRET-based aptamer biosensor for selective and sensitive detection of aflatoxin $\mathrm{B}_{1}$ in peanut and rice. Food Chem. 2017;220: 527-32. https://doi.org/10.1016/j.foodchem.2016.10.004.

146. Chen X, Bai X, Li H, Zhang B. Aptamer-based microcantilever array biosensor for detection of fumonisin $\mathrm{B}_{1}$. RSC Adv. 2015;5: 35448-52. https://doi.org/10.1039/c5ra04278j.

147. Guo X, Wen F, Zheng N, Li S, Fauconnier M-L, Wang J. A qPCR aptasensor for sensitive detection of aflatoxin $\mathrm{M}_{1}$. Anal Bioanal Chem. 2016;408:5577-84. https://doi.org/10.1007/s00216-0169656-z.

148. Samokhvalov AV, Safenkova IV, Eremin SA, Zherdev AV, Dzantiev BB. Use of anchor protein modules in fluorescence polarisation aptamer assay for ochratoxin A determination. Anal Chim Acta. 2017;962:80-7. https://doi.org/10.1016/j.aca.2017. 01.024.

149. Li Q, Lu Z, Tan X, Xiao X, Wang P, Wu L, et al. Ultrasensitive detection of aflatoxin $\mathrm{B}_{1}$ by SERS aptasensor based on exonuclease-assisted recycling amplification. Biosens Bioelectron. 2017;97:59-64. https://doi.org/10.1016/j.bios.2017.05.031.

150. Abnous K, Danesh NM, Alibolandi M, Ramezani M, Sarreshtehdar Emrani A, Zolfaghari R, et al. A new amplified $\pi$-shape electrochemical aptasensor for ultrasensitive detection of aflatoxin $\mathrm{B}_{1}$. Biosens Bioelectron. 2017;94:374-9. https:/ doi.org/10.1016/j.bios.2017.03.028.

151. Wang S, Zhang Y, Pang G, Zhang Y, Guo S. Tuning the aggregation/disaggregation behavior of graphene quantum dots by structure-switching aptamer for high-sensitivity fluorescent ochratoxin A sensor. Anal Chem. 2017;89:1704-9. https://doi. org/10.1021/acs.analchem.6b03913.

152. Benito-Peña E, Valdés MG, Glahn-Martínez B, Moreno-Bondi MC. Fluorescence based fiber optic and planar waveguide biosensors. A review. Anal Chim Acta. 2016;943:17-40. https://doi.org/ 10.1016/j.aca.2016.08.049.

153. Cho EJ, Lee JW, Ellington AD. Applications of aptamers as sensors. Annu Rev Anal Chem. 2009;2:241-64. https://doi.org/10. 1146/annurev.anchem.1.031207.112851.

154. Zhao Y, Chen F, Li Q, Wang L, Fan C. Isothermal amplification of nucleic acids. Chem Rev. 2015;115:12491-545. https://doi.org/ 10.1021/acs.chemrev.5b00428.

155. Huang H, Qin J, Hu K, Liu X, Zhao S, Huang Y. Novel autonomous protein-encoded aptamer nanomachines and isothermal exponential amplification for ultrasensitive fluorescence polarization sensing of small molecules. RSC Adv. 2016;6:86043-50. https:// doi.org/10.1039/c6ra17959b.

156. Seok Y, Byun JY, Shim WB, Kim MG. A structure-switchable aptasensor for aflatoxin $\mathrm{B}_{1}$ detection based on assembly of an aptamer/split DNAzyme. Anal Chim Acta. 2015;886:182-7. https://doi.org/10.1016/j.aca.2015.05.041.

157. Ren C, Li H, Lu X, Qian J, Zhu M, Chen W, et al. A disposable aptasensing device for label-free detection of fumonisin $\mathrm{B}_{1}$ by integrating PDMS film-based micro-cell and screen-printed carbon electrode. Sensors Actuators B Chem. 2017;251:192-9. https://doi.org/10.1016/j.snb.2017.05.035.

158. Lv X, Zhang Y, Liu G, Du L, Wang S. Aptamer-based fluorescent detection of ochratoxin A by quenching of gold nanoparticles. RSC Adv. 2017;7:16290-4. https://doi.org/10.1039/c7ra01474k.

159. Sharma A, Hayat A, Mishra RK, Catanante G, Bhand S, Marty JL. Titanium dioxide nanoparticles $\left(\mathrm{TiO}_{2}\right)$ quenching based 
aptasensing platform: application to ochratoxin A detection. Toxins. 2015;7:3771-84. https://doi.org/10.3390/toxins7093771.

160. Lv L, Li D, Cui C, Zhao Y, Guo Z. Nuclease-aided target recycling signal amplification strategy for ochratoxin A monitoring. Biosens Bioelectron. 2017;87:136-41. https://doi.org/10.1016/j.bios.2016. 08.024 .

161. Zhang J, Li Z, Zhao S, Lu Y. Size-dependent modulation of graphene oxide-aptamer interactions for an amplified fluorescence-based detection of aflatoxin $\mathrm{B}_{1}$ with a tunable dynamic range. Analyst. 2016;141:4029-34. https://doi.org/10. 1039/c6an00368k.

162. Chen J, Wen J, Zhuang L, Zhou S. An enzyme-free catalytic DNA circuit for amplified detection of aflatoxin $\mathrm{B}_{1}$ using gold nanoparticles as colorimetric indicators. Nanoscale. 2016;8:9791-7. https://doi.org/10.1039/c6nr01381c.

163. Dai S, Wu S, Duan N, Chen J, Zheng Z, Wang Z. An ultrasensitive aptasensor for ochratoxin A using hexagonal core/shell upconversion nanoparticles as luminophores. Biosens Bioelectron. 2017;91:538 44. https://doi.org/10.1016/j.bios.2017.01.009.

164. Duan N, Wu S, Dai S, Gu H, Hao L, Ye H, et al. Advances in aptasensors for the detection of food contaminants. Analyst. 2016;141:3942-61. https://doi.org/10.1039/c6an00952b.

165. Machinek RR, Ouldridge TE, Haley NE, Bath J, Turberfield AJ. Programmable energy landscapes for kinetic control of DNA strand displacement. Nat Commun. 2014;5:5324. https://doi.org/ 10.1038/ncomms6324.

166. Huang L, Wu J, Zheng L, Qian H, Xue F, Wu Y, et al. Rolling chain amplification based signal-enhanced electrochemical aptasensor for ultrasensitive detection of ochratoxin A. Anal Chem. 2013;85:10842-9. https://doi.org/10.1021/ac402228n.

167. Bianco M, Sonato A, De Girolamo A, Pascale M, Romanato F, Rinaldi R, Arima V. An aptamer-based SPR-polarization platform for high sensitive OTA detection. Sensors Actuators B Chem 2017;241:314-320. doi:https://doi.org/10.1016/j.snb.2016.10. 056.

168. Ruffato G, Pasqualotto E, Sonato A, Zacco G, Silvestri D, Morpurgo M, De Toni A, Romanato F. Implementation and testing of a compact and high-resolution sensing device based on grating-coupled surface plasmon resonance with polarization modulation. Sensors Actuators B Chem 2013;185:179-187. doi: https://doi.org/10.1016/j.snb.2013.04.113.

169. Moreno-Bondi M, Urraca J, Navarro F, Carrasco S. Preparation of molecularly imprinted polymers. In: Alvarez-Lorenzo C, Concheiro A, editors. Molecularly imprinted polymers: a handbook for academia and industry. Shawbury: Smithers Rapra; 2013. p. 23-86.

170. Li S, Ge Y, Piletsky SA, Lunec J. Molecularly imprinted sensors: Overview and applications. Amsterdam: Elsevier; 2012.

171. Haupt K. Molecular imprinting. Berlin: Springer; 2012.

172. Mirsky V, Yatsimirsky A. Artificial receptors for chemical sensors. Weinheim: Wiley-VCH; 2011.

173. Pieltsky SA, Whitcombe MJ. Designing receptors for the next generation of biosensors. Berlin: Springer; 2013.

174. Lee SW, Kunitake T. Handbook of molecular imprinting. Advanced sensor applications. Singapore: Pan Stanford Publishing; 2013.

175. Wang S, Zhu X, Zhao M. Optical sensors based on molecularly imprinted nanomaterials. In: Li S, Le Y, Li H, editors. Smart nanomaterials for sensor application. Oak Park: Bentham; 2012. p. 60-75.

176. Alvarez-Lorenzo C, Concheiro A. Molecularly imprinted polymers: a handbook for academia and industry. Shawbury: Smithers Rapra; 2013.

177. Chen L, Wang X, Lu W, Wu X, Li J. Molecular imprinting: perspectives and applications. Chem Soc Rev. 2016;45:2137-211.
178. Haupt K. Biomaterials: plastic antibodies. Nat Mater. 2010;9:6124. https://doi.org/10.1038/nmat2818.

179. Moreno-Bondi MC, Navarro-Villoslada F, Benito-Peña E, Urraca JL. Molecularly imprinted polymers as selective recognition elements in optical sensing. Curr Anal Chem. 2008;4:316-40. https:// doi.org/10.2174/157341108785914925.

180. Moreno-Bondi MC, Benito-Peña M, Urraca JL, Orellana G. Immuno-like assays and biomimetic microchips. Top Curr Chem. 2012;325:114-64. https://doi.org/10.1007/128_2010_94.

181. Jiang M, Braiek M, Florea A, Chrouda A, Farre C, Bonhomme A, et al. Aflatoxin $\mathrm{B}_{1}$ detection using a highly-sensitive molecularlyimprinted electrochemical sensor based on an electropolymerized metal organic framework. Toxins. 2015;7:3540-53. https://doi. org/10.3390/toxins7093540.

182. Wang Z, Li J, Xu L, Feng Y, Xiaoquan L. Electrochemical sensor for determination of aflatoxin $B_{1}$ based on multiwalled carbon nanotubes-supported $\mathrm{Au} / \mathrm{Pt}$ bimetallic nanoparticles. J Solid State Electrochem. 2014;18:2487-96. https://doi.org/10.1007/ s10008-014-2506-z.

183. Fang G, Liu G, Yang Y, Wang S. Quartz crystal microbalance sensor based on molecularly imprinted polymer membrane and three-dimensional Au nanoparticles@mesoporous carbon CMK3 functional composite for ultrasensitive and specific determination of citrinin. Sensors Actuators B Chem. 2015;230:272-80. https://doi.org/10.1016/j.snb.2016.02.053.

184. Choi SW, Chang HJ, Lee N, Chun HS. A surface plasmon resonance sensor for the detection of deoxynivalenol using a molecularly imprinted polymer. Sensors. 2011;11:8654-64. https://doi. org/10.3390/s110908654.

185. Zhang W, Xiong H, Chen M, Zhang X, Wang S. Surfaceenhanced molecularly imprinted electrochemiluminescence sensor based on $\mathrm{Ru} @ \mathrm{SiO}_{2}$ for ultrasensitive detection of fumonisin $\mathrm{B}_{1}$. Biosens Bioelectron. 2017;96:55-61. https://doi.org/10.1016/ j.bios.2017.04.035.

186. Wang Q, Chen M, Zhang H, Wen W, Zhang X, Wang S. Solidstate electrochemiluminescence sensor based on RuSi nanoparticles combined with molecularly imprinted polymer for the determination of ochratoxin A. Sensors Actuators B Chem. 2016;22: 264-9. https://doi.org/10.1016/j.snb.2015.08.057.

187. Pacheco JG, Castro M, Machado S, Barroso MF, Nouws HPA, Delerue-Matos C. Molecularly imprinted electrochemical sensor for ochratoxin A detection in food samples. Sensors Actuators B Chem. 2015;215:107-12.

188. Zhang W, Han Y, Chen X, Luo X, Wang J, Yue T, et al. Surface molecularly imprinted polymer capped Mn-doped ZnS quantum dots as a phosphorescent nanosensor for detecting patulin in apple juice. Food Chem. 2017;232:145-54. https://doi.org/10.1016/j. foodchem.2017.03.156.

189. Xu L, Fang G, Pan M, Wang X, Wang S. One-pot synthesis of carbon dots-embedded molecularly imprinted polymer for specific recognition of sterigmatocystin in grains. Biosens Bioelectron. 2016;77:950-6. https://doi.org/10.1016/j.bios.2015.10.072.

190. Fang G, Fan C, Liu H, Pan M, Zhu H, Wang S. A novel molecularly imprinted polymer on $\mathrm{CdSe} / \mathrm{ZnS}$ quantum dots for highly selective optosensing of mycotoxin zearalenone in cereal samples. RSC Adv. 2014;4:2764-71. https://doi.org/10.1039/ C3RA45172K.

191. Urraca JL, Marazuela MD, Merino ER, Orellana G, MorenoBondi MC. Molecularly imprinted polymers with a streamline mimic of zeralenone analysis. J Chromatogr A. 2006;1116:12734. https://doi.org/10.1016/j.chroma.2006.03.032.

192. Ton XA, Acha V, Bonomi P, Tse Sum Bui B, Haupt K. A disposable evanescent wave fiber optic sensor coated with a molecularly imprinted polymer as a selective fluorescence probe. Biosens Bioelectron. 2015;64:359-66. https://doi.org/10.1016/j.bios. 2014.09.017. 